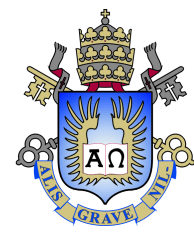

Lisa Orsi Beihy Pacheco

\title{
Oligopsony Power in Labor Markets: Evidence from a Payroll Tax Reform
}

Dissertação de Mestrado

Thesis presented to the Programa de Pós-graduação em Economia, do Departamento de Economia da PUC-Rio in partial fulfillment of the requirements for the degree of Mestre em Economia.

Advisor : Prof. Gustavo Gonzaga

Co-advisor: Prof. Leonardo Rezende 


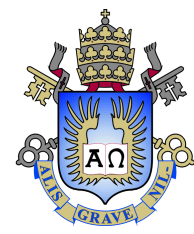

\title{
Lisa Orsi Beihy Pacheco
}

\section{Oligopsony Power in Labor Markets: Evidence from a Payroll Tax Reform}

Thesis presented to the Programa de Pós-graduação em Economia da PUC-Rio in partial fulfillment of the requirements for the degree of Mestre em Economia. Approved by the Examination Committee:

\author{
Prof. Gustavo Gonzaga \\ Advisor \\ Departamento de Economia - PUC-Rio \\ Prof. Leonardo Rezende \\ Co-advisor \\ Departamento de Economia - PUC-Rio
}

Prof. Renata Narita

Universidade de São Paulo (USP)

Dr. Carlos Henrique Corseuil

Instituto de Pesquisa Econômica Aplicada (IPEA)

Rio de Janeiro, April the $16^{\text {th }}, 2021$ 
All rights reserved.

\section{Lisa Orsi Beihy Pacheco}

B.A. in Economics, Universidade de São Paulo (USP), 2018

Bibliographic data

Pacheco, Lisa Orsi Beihy

Oligopsony Power in Labor Markets: Evidence from a Payroll Tax Reform / Lisa Orsi Beihy Pacheco; advisor: Gustavo Gonzaga; co-advisor: Leonardo Rezende. - 2021.

$61 \mathrm{f}$ : il. color. ; $30 \mathrm{~cm}$

Dissertação (mestrado) - Pontifícia Universidade Católica do Rio de Janeiro, Departamento de Economia, 2021.

Inclui bibliografia

1. Economia - Teses. 2. Economia do Trabalho - Teses. 3. Oligopsônio. 4. Desoneração da folha de pagamento. 5. Elasticidade-salário da oferta de trabalho. I. Gonzaga, Gustavo. II. Rezende, Leonardo. III. Pontifícia Universidade Católica do Rio de Janeiro. Departamento de Economia. IV. Título. 
To my parents, for their support and encouragement.

To Juliano, for his love and understanding. 


\section{Acknowledgments}

I would like to thank my advisors Prof. Gustavo Gonzaga and Prof. Leonardo Rezende, whose insightful comments and contributions were essential to this research. Any mistakes are my own.

I thank the Brazilian Ministry of Labor, which, through the Programa de Disseminação de Estatísticas do Trabalho, has granted PUC-Rio access to the information collected by RAIS. This research would not have been possible without their help.

I am thankful to my parents, Carlos and Carla, and my brother Marcelo, for always believing in me and pushing me forward. I am especially thankful to Juliano, for his endless support and companionship.

Finally, my experience at PUC would not have been the same without the company of my classmates - Arthur Cordeiro, Arthur Brito, Henrique, João, Luiz Guilherme, Mateus and Rafaela - and I am grateful for their friendships.

This study was financed in part by the Coordenação de Aperfeiçoamento de Pessoal de Nível Superior - Brasil (CAPES) - Finance Code 001. I also gratefully acknowledge funding from PUC-Rio and FAPERJ. 


\section{Abstract}

Pacheco, Lisa Orsi Beihy; Gonzaga, Gustavo (Advisor); Rezende, Leonardo (Co-Advisor). Oligopsony Power in Labor Markets: Evidence from a Payroll Tax Reform. Rio de Janeiro, 2021. 61p. Dissertação de Mestrado - Departamento de Economia, Pontifícia Universidade Católica do Rio de Janeiro.

Understanding non-competitive behavior in labor markets has become crucial to gain insight into labor market dynamics, and estimating labor supply wage elasticities can help determine the existence of oligopsony power. By building on Manning (2003), I use matched employer-employee data, and take advantage of sector-specific shocks to payroll taxes, to estimate labor supply wage elasticities for the Brazilian labor market. I estimate separation and recruitment elasticities using an IV approach that allows for the identification of exogenous variation in wages through the reform on payroll taxes implemented in Brazil, which represents shocks to labor demand. While standard OLS estimates are low (and unrealistic) as in the recent literature, estimates using the IV approach are much more reasonable. Results indicate that there exists considerable labor market power by firms in Brazil, with a market-level elasticity of 1.4 and a firm-level elasticity of 4.4. Finally, I evaluate whether oligopsony power is different between skill levels, as well as between more or less urbanized and informal municipalities. I find that firms exert higher markdowns for low-skill workers, and that higher labor market power is correlated with lower urbanization and higher informality.

\section{Keywords}

Oligopsony; Payroll tax exemption; Labor supply wage elasticity. 


\section{Resumo}

Pacheco, Lisa Orsi Beihy; Gonzaga, Gustavo; Rezende, Leonardo. Oligopsônio no mercado de trabalho: Evidências da desoneração da folha de pagamento. Rio de Janeiro, 2021. 61p. Dissertação de Mestrado - Departamento de Economia, Pontifícia Universidade Católica do Rio de Janeiro.

Analisar comportamentos não-competitivos no mercado de trabalho tem se tornado um aspecto crucial para melhorar a compreensão das dinâmicas do mercado de trabalho, e estimar elasticidades-salário da oferta de trabalho pode auxiliar a determinar a existência de estruturas de oligopsônio. Ao construir sobre Manning (2003), uso dados de contratos identificados por empregadorempregado, e aproveito choques específicos de desonerações na folha de pagamento, para estimar elasticidades-salário da oferta de trabalho para o mercado de trabalho brasileiro. Estimamos elasticidades-salário de separações e contratações utilizando de uma abordagem por IV que permite a identificação de variações exógenas nos salários, através da desoneração implementada no Brasil, que representa choques à demanda por trabalho. Enquanto estimativas padrão por MQO são baixas (e irrealistas) como na literatura recente, estimativas usando a abordagem de variáveis instrumentais são muito mais razoáveis. Os resultados indicam a existência de considerável poder de mercado pelo lado de firmas no mercado de trabalho no Brasil, com a elasticidade no nível do mercado de 1.4 e no nível da firma de 4.4. Finalmente, avaliamos se o poder de oligopsônio das firmas difere entre níveis de qualificação, e entre municípios mais ou menos urbanos e informais. Encontramos que as firmas exertem maiores markdowns para trabalhadores menos qualificados, e que maior poder de mercado das firmas está correlacionado com menor urbanização e maior informalidade.

\section{Palavras-chave}

Oligopsônio; Desoneração da folha de pagamento; Elasticidade-salário da oferta de trabalho. 


\section{Table of contents}

$1 \quad$ Introduction $\quad 13$

$\begin{array}{lll}1.1 & \text { Related literature } & 15\end{array}$

2 Institutional Background $\quad 19$

2.1 The effects of the payroll tax reform 24

$3 \quad$ Data and Empirical Strategy 25

$\begin{array}{lll}3.1 & \text { Data } & 25\end{array}$

3.2 Framework 31

3.3 Empirical Strategy $\quad 34$

4 Results $\quad 38$

$\begin{array}{lll}4.1 & \text { Robustness exercises } & 42\end{array}$

5 Conclusion $\quad 49$

$\begin{array}{ll}\text { A Appendix } & 56\end{array}$ 


\section{List of figures}

Figure A.1 Share treated by the payroll tax reform, by micro-region 57

Figure A.2 Share of households in urban areas, by micro-region 60

Figure A.3 Share of workers in the informal sector, by micro-region 61 


\section{List of tables}

Table 2.1 MPs and legislation of the payroll tax reform 22

Table 2.2 Share of industry level outcomes from NCM products 23

$\begin{array}{lll}\text { Table } 3.1 & \text { Summary statistics } & 28\end{array}$

Table 3.2 Summary statistics for municipal share urban and informality quartiles $\quad 29$

Table 3.3 Summary statistics by skill level 31

$\begin{array}{lll}\text { Table 3.4 } & \text { Stock-based labor supply wage elasticity } & 37\end{array}$

Table 4.1 First stage \& Weak instrument test 39

Table 4.2 Firm-level labor supply wage elasticity 40

Table 4.3 Firm-level labor supply wage elasticity by urbanization and informality 42

Table 4.4 Labor supply wage elasticity by skill level 43

Table 4.5 Contract-level labor supply wage elasticity 44

Table 4.6 Labor supply wage elasticity by urbanization and informality $\quad 45$

Table 4.7 Fixed effects robustness exercises 46

Table 4.8 Robustness exercises for firm size and transition cycle 47

Table 4.9 Robustness exercises by municipal-level rates of informality 48

Table 4.10 Robustness exercises by municipal-level rates of urbanization 48

Table A.1 Summary statistics by population and sample 56

Table A.2 Summary statistics for municipalities $\quad 57$

Table A.3 Qualification level descriptions 58

Table A.4 Summary statistics by QBQ skill level $\quad 59$

Table A.5 Robustness exercises for reduced CNAE sample 59 


\section{List of Abreviations}

PBM - Plano Brasil Maior

MP - Medida Provisória

RAIS - Registro Anual de Informação Social

CNAE - Classificação Nacional de Atividades Econômicas

NCM - Mercosur Common Nomenclature

PIA - Pesquisa Industrial Anual

MTE - Ministério do Trabalho e Emprego

CLT - Consolidação das Leis do Trabalho

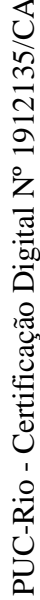

FGTS - Fundo de Garantia do Tempo de Serviço

QBQ - Quadro Brasileiro de Qualificações

CBO - Classificação Brasileira de Ocupações

IBGE - Instituto Brasileiro de Geografia e Estatística

EQF - European Qualifications Framework 
There is nothing like looking, if you want to find something. You certainly usually find something, if you look, but it is not always quite the something you were after.

J. R. R. Tolkien, The Hobbit. 


\section{Introduction}

In recent years, the decreasing share of labor in national income across several developed countries has led to increased interest in the idea that firms and workers hold unequal economic power in labor markets (Manning, 2020) ${ }^{1}$. Moreover, whether firms exercise power in labor markets is a central issue to understanding how wages are determined and how labor market policies take effect. As such, there has been a recent surge in literature that seek to estimate the amount of employer market power. The paper aims to measure the extent of this market power for the Brazilian labor market, using a novel approach to estimate worker-flows (recruitment and separation) elasticities with respect to wages through an IV strategy that accounts for the endogeneity of wages.

The paper builds on Manning (2003) by introducing an IV approach and using high quality administrative data on Brazilian labor contracts. The empirical strategy proposed is to use an exogenous shock to labor demand as an instrument for wages. This exogenous shock is the payroll tax reform implemented in Brazil since 2011. Using observational matched employeremployee data can lead to several biases on elasticity estimates (Bassier et al., 2020). For instance, if wages are determined by worker and firm components, then estimations of the effect of wages on separation and recruitment rates will be biased due to unobserved worker and firm characteristics that are related to both wages and hiring/quitting decisions. Therefore, using instruments is crucial to identifying exogenous variation in wages and consequently estimating worker-flows wage elasticities. In this respect, the paper contributes to the literature by providing an instrument that can overcome these biases.

The payroll tax reform announced in 2011 was one of the several industrial policies adopted by the Brazilian government in its attempt to create incentives to increase competitiveness, technological progress and investments.

\footnotetext{
${ }^{1}$ Guerriero (2019) uses country-level panel data to study the evolution of the labor share across 151 economies. She presents six different approaches to estimating the labor share, with specific adjustments for the inclusion of the self-employed. Her preferred specification attributes the average employee's wage to all those workers who hold self-employment jobs but are not classified as employers. For Brazil, she finds that between 1990 and 2010 the labor share of national income increased. While this stands in contrast to the experience of most developed countries, understanding the structure of oligopsony power in labor markets is still essential to throw light onto why and how these movements are happening.
} 
This particular policy aimed at reducing distortions in the labor market by lowering payroll taxes, and thus allowing firms to better adjust inputs. Specifically, this reform substituted the $20 \%$ contribution on the payroll bill made by employers to the federal pension fund system by a gross revenue (excluding exports) tax. Firms were contemplated by the policy either through their CNAE sector identifiers or the products they manufacture and sell. The reform was initially announced for only four sectors, but by the end of 2014 had been expanded to contemplate a few dozen sectors. In the end of 2015, there was also a significant change to the policy, with the announcement that firms would be able to choose whether to contribute through the $20 \%$ payroll tax or through the gross revenue tax.

I build treatment variables which indicate whether a given firm was affected by the payroll tax reform. Most studies which use this reform restrain their samples only to sectors included in the reform through CNAE sector identifiers. Here, I use a novel approach to identify firms also included through product identifiers, by linking sectors which encompass the products contemplated by the reform. Not including these sectors may lead to a conservative analysis of the reform's effects, since the products included represent around $42 \%$ of total production and sales in their respective sectors.

By using data on Brazilian formal labor contracts between 2012 and 2015, I follow Manning (2003)'s semi-structural framework to estimate separation and recruitment elasticities with respect to wages. I also use firm-level observations to estimate firm-level wage elasticities for the Brazilian labor market. Since the policy shock affected individual firms as a whole, this specification may allow for better identifying treatment effects. In particular, the payroll tax exemption implemented by the reform reflects a shock that shifts the labor demand curve at the firm level (Borjas, 2016, chap. 2), leading to an exogenous effect on wages. The resulting estimates indicate that including the treatment effects of sectors contemplated through product lists is crucial to a clean identification of wage elasticities. The full specification, including treatment effects using both lists, presents a market-level labor supply wage elasticity of 1.4 and a firm-level estimate of 4.4. These estimates imply first that labor supply is relatively inelastic with respect to wages in Brazil, and secondly that firms exert markdowns on wages of around $20 \%$.

A second goal of this research is to present estimates of labor supply wage elasticities for different sub-samples of the data. There is a large literature which relates labor market power to skill level heterogeneity, urbanization, and the presence of informality. First, I provide insights by estimating measures of oligopsony power for different skill levels, using the "Quadro Brasileiro de 
Qualificações" framework that associates occupational codes reported in the matched employer-employee data to 8 distinct levels of qualification. I find that labor supply wage elasticities are lower for low skilled workers, indicating that firms exert more control in determining wages for low-skill occupations. As for the relationship of market power and both urbanization and informality, I use Census data to calculate the share of households in urban areas and the share of workers in informality at the municipal level. By estimating labor supply wage elasticities for workers in municipalities below and above the median of these measures, I find that higher markdowns are correlated with lower urbanization and higher informality.

\section{1}

\section{Related literature}

A vast recent literature has aimed to provide empirical evidence of a negative correlation between concentration of firms in the labor market and wages (Azar et al., 2017; Benmelech et al., 2018; Abel et al., 2018; Martins, 2018; Marinescu et al., 2020) and thus provide support for the hypothesis of monopsony in labor markets. The intent of this paper is to contribute on the following strands of the literature.

First, a large part of the existing literature that has attempted to estimate labor supply elasticity has followed Manning (2003), who uses a dynamic monopsony model to decompose it into worker-flows elasticities, and shows that, under steady state assumptions, the labor supply elasticity is equal to a linear combination of recruitment and separation rate elasticities. Initial research using this approach used exogenous shocks to wages in local labor markets as a way to estimate these elasticities, usually focusing on occupations, such as teachers or nurses (Staiger et al., 2010; Falch, 2010; Ransom and Sims, 2010; Matsudaira, 2014). These estimates varied widely - from close to zero to almost 4 - pointing towards significant heterogeneity in firms' oligopsony power across industries and countries.

The most recent research that has aimed at estimating these elasticities has attempted to use mostly experimental data on recruiting and quitting, and estimating wage elasticities using separate datasets ${ }^{2}$. Bó et al. (2013) find a wage elasticity of applications of 2 , by analyzing the impact of randomizing wage offers in the Mexican public sector. Azar et al. (2020) use data from an online job posting website, and find a wage elasticity of applications of 0.43 , while Banfi and Villena-Roldán (2019) use data for Chilean job advertisements

\footnotetext{
${ }^{2}$ See Manning (2020) for a more complete overview of the recent literature on estimating worker-flows elasticities, and Sokolova and Sorensen (2018) for a survey of "best practice" estimates.
} 
and find an application elasticity of 0.25 . Using both experimental and observational data from MTurk, Dube et al. (2020) find similarly low wage elasticities of applications.

As for overall labor supply elasticities, Azar et al. (2019) follow standard techniques in estimating product demand elasticities from the IO literature. Using data on job applications in the US they estimate a firm-level wage elasticity of 5.8. While higher than most estimates in the literature, it still reflects considerable labor market power from firms. Caldwell and Oehlsen (2018) use quasi-experimental results from ride-share workers in two US cities to estimate wage elasticities between 2 and 4, and Webber (2015) presents estimates between 1 and 1.2 using data from the US Census Bureau. Dube et al. (2019) use exogenous and discontinuous salary raises at a major U.S. retailer, and find firm-level elasticities of around 4. This paper aims to contribute to this literature by estimating these measures instrumenting for wages with shocks to labor demand, providing a methodology that can overcome issues of endogeneity.

In addition, some research has also attempted to estimate labor supply wage elasticities for the Brazilian labor market. Vick (2017) focuses on gender inequality in the 1990s and finds an overall wage elasticity between 1 and 2. Lagos (2020) also estimates a labor supply wage elasticity of around 2, by analysing the behavior and presence of strong unions through Collective Bargaining Agreements in Brazilian sectors. On the other hand, by using growth measures as instruments Tucker (2017) reports a wage elasticity of separation of around -0.3 .

Some recent attempts have also been made to relate labor market power to policy effects in the Brazilian labor market. In particular, Narita et al. (2020) use the staggered roll-out of the same payroll tax reform to evaluate its effects under the light of labor market competition. First, by computing HHI indexes of labor market concentration, they show that there is significant heterogeneity in concentration throughout the country. Second, they find that the effects of the reform on wages and employment is driven mostly by local labor markets with low levels of concentration, indicating that the presence of monopsony power can be a useful tool in anticipating the effects of labor policies. This paper attempts to contribute to this literature by providing further insight into the presence of labor market power in Brazil, and into the relationship between monopsony power and labor policies.

Lastly, there is also a broad literature that relates oligopsony power with labor market features such as urbanization, skill, and the presence of informality. Higher urbanization can lead to higher competition among firms 
and lower markdowns on wages, and there is evidence to support the positive relationship between agglomeration and wages - be it through better matching, the accumulation of human capital or the sorting of high-skilled workers into urban areas (Combes et al., 2012; Baum-Snow and Pavan, 2012; Behrens et al., 2014). There is also related research that has identified the relevance of urbanization on the wage distribution across different margins such as worker-firm matching quality and gender (D'Costa and Overman, 2014; Dauth et al., 2019; Bonanno and Lopez, 2012; Nisic, 2017). Some recent literature has also provided insights into the heterogeneity of wages with respect to routine versus non-routine tasks (Bachmann et al., 2020) and along the wage distribution (Webber, 2015), with mixed interpretations as to whether better skills are related to higher or lower wage markdowns. Notably, Azar et al. (2019) borrow from the IO literature on estimating discrete choice models to characterize labor supply and estimate the elasticity of applications. They find that urbanization and higher skill are both positively correlated with higher competition among firms (and therefore lower markdowns), which they relate to the existence of more outside options for workers - especially in the case of urban versus rural labor markets. Additionally, Almeida et al. (2020) use Brazilian survey data to show that the urban scale is relevant to identify wage premiums for informal and formal labor markets.

As for the effect of informality on firms' labor market power, Perry et al. (2007) provide two contrasting interpretations of the origins of informality and the ensuing consequences for oligopsony power in labor markets. The exit interpretation describes informality as a choice at the individual level, such that agents "make implicit cost-benefit analyses about whether to cross the relevant margin into formality, and frequently decide against it". The second interpretation, of exclusion, identifies informality as the result of barriers between the informal and formal markets - these being either segmentation, entry regulations or regulatory burdens. Both these interpretations suggest that labor supply wage elasticities and informality being positively or negatively correlated depends on whether formal and informal labor markets are segmented or not. If labor markets are not segmented, then the exit view would imply that higher informality is correlated with higher wages (i.e. lower markdowns) in the formal sector - that is, formal and informal firms compete for workers and there is less room for formal firms to push wages downward. If labor markets are segmented, then the exclusion view would imply that higher informality is correlated with substantial barriers for formality which give formal firms more power to determine wages (i.e. higher markdowns).

Empirical evidence on this issue has generally favored the notion that 
formal and informal labor markets are segmented ${ }^{3}$, and therefore that higher informality would be correlated with lower labor supply wage elasticities. Empirical studies in Brazil have indicated that there is substantial segmentation between formal and informal markets (da Silva and Pero, 2008; Dalberto and Cirino, 2018). In particular, Ulyssea (2018) models informality along two margins: an extensive margin (whether the firm is formal or informal) and an intensive margin (whether the firm will hire formal or informal workers). He shows that formality in both margins is increasing in productivity (which is one-to-one with firm size in his model), and therefore low-productivity formal firms are the ones most affected by the presence of informality. Using data for Brazil, he finds that $17 \%$ of all informal firms are informal because of the high regulatory costs that prohibit entry into formality; $38 \%$ of informal firms are firms that are productive enough to survive in the formal sector, but choose not to so as to earn higher profits; and the remaining $45 \%$ are firms that are too unproductive to survive in the formal sector. In this respect, his findings support the hypothesis that, for larger firms, formal and informal markets tend to be more segmented ${ }^{4}$. Nevertheless, there is also some support in the literature to the argument that there is little empirical content to the segmentation hypothesis (Ulyssea, 2010). This paper aims to provide insight into these discussions by estimating labor supply wage elasticities for labor market partitions using urbanization, informality and skill level segmentation.

\footnotetext{
${ }^{3}$ For instance, Alcaraz et al. (2015) find some evidence on segmentation in Mexico, and Bertranou et al. (2014) find compelling evidence of segmentation in informality in Argentina.

${ }^{4}$ Through his theoretical framework, Ulyssea (2018) shows that smaller formal firms are the most responsible for the intensive margin of informality (that is, formal firms that hire informal workers) precisely because they are less productive and therefore look to this margin to reduce costs - but also because there are larger costs to informality as firm size increases. Using Brazilian data, he finds that the probability of an informal firm having more than 10 employees is extremely low, and that informal firms usually pay lower wages. Both these results, as well as his theoretical predictions with respect to the potential effects of formalization policies, indicate that large formal firms do not compete with informal firms. However, it is important to highlight that most of these results stem from the hypothesis in Ulyssea (2018) that firm size and productivity are one-to-one.
} 


\section{2}

\section{Institutional Background}

The Brazilian tax system allows firms to be allocated into one of two possible tax regimes at the beginning of each calendar year. The standard regime requires firms to pay a flat payroll tax of $20 \%$ designated for social security, a severance contribution of $8.5 \%$, in addition to contributions to workers protection and education entities (such as SESI, SENAC and SEBRAE) and an insurance levy for labor related accidents (SAT) - the last two adding up to almost $9 \%$ over the payroll bill. Firms are also required under this standard regime to pay additional corporate taxes (CSLL and IRPJ) on either gross or net income according to revenue size ${ }^{1}$. The second tax regime, entitled SIM$P L E S$, allows micro, small and medium firms to collect a unique tax levy on gross revenues. This regime was implemented in December 1996, and proposed a differentiated tax system that would reduce red tape, consolidate taxes and contributions to simplify payments, as well as lower the overall tax burden (Monteiro and Assunção, 2012).

In August 2011 the Brazilian government announced a set of public policies aimed at stimulating competitiveness, raising investments and increasing incentives for technical progress, entitled "Plano Brasil Maior" (PBM). One of such policies was a comprehensive tax reform, supposed to be implemented in four parts to facilitate political approval (Werneck, 2013). This package included the payroll tax reform, which changed how companies contributed to the federal pension fund system. It consisted of substituting the mandatory contribution of $20 \%$ of the payroll bill by a tax on gross revenues (excluding exports $)^{2}$. There was significant subsidy by the government for the reform, because the change in contribution implied considerable losses in tax revenue.

The main argument behind the policy was that payroll taxes make labor more expensive and discourage the creation of formal jobs. Therefore, by reducing this distortion, the government would be creating incentives for firms to hire more and become more competitive, as well as reduce informality. A secondary goal was to negatively impact prices, and increase output. It is also worth noting that Brazil had one of the highest tax rates levied on payroll bills,

${ }^{1}$ This regime is governed by Law 8212, of July $24,1991$.

${ }^{2}$ Initially the additional tax on gross revenues was of $2.5 \%$ for service sectors and $1.5 \%$ for manufacturing firms, but were later altered in August 2012 to $2 \%$ and 1\%, respectively. 
at $37.5 \%$ (Ulyssea, 2018), and reducing this extra cost had been a constant demand from the private sector since the early 1990s (Werneck, 2013). Since the policy exempted exports from the revenue tax, one of its secondary goals was also to increase the competitiveness of exporting firms. Finally, the policy was not applicable to firms who operated under the simplified tax regime SIMPLES. In 2012 the regulation of this simplified regime covered firms with up to $\mathrm{R} \$ 3.6$ million in annual revenues, such that the payroll tax reform affected mostly medium and large firms, as well as small firms that did not opt for the simplified tax regime.

Not only did the policy reduce the distortions imposed on labor costs, it also significantly reduced the amount of taxes paid by firms. The choice to not only reduce the payroll tax but to substitute its corresponding contribution by a revenue tax was mostly due to the need of maintaining the level of tax revenue reverted towards the federal pension fund system. ABDI (2014) estimates the losses in tax revenue for the government at about $\mathrm{R} \$ 20$ billion in the first two years, and another $\mathrm{R} \$ 90$ billion between 2013 and 2017 .

The reform was rolled out through both Provisional Measures (MPs) ${ }^{3}$ and legislation that consolidated the measures. The criteria used for inclusion into the reform was either through standard 5-digit CNAE sectors, 7-digit CNAE sectors or through product codes from the Mercosur Common Nomenclature $(\mathrm{NCM})^{4}$. If a firm was included in the reform through its sector identifier, the entirety of its revenue was subject to the tax change. Since the policy listed only final products through the NCM lists, firms contemplated through product identifiers were subject to partial exemption in their payroll tax according to how much of their revenue originated from final products included in the reform. For example, if only half of a firm's revenue was derived from products that were contemplated, then the reduction on the firm's payroll tax would be $50 \%$, and the additional revenue tax would be levied on $50 \%$ of its gross revenues.

Although the change in the method of contribution was initially manda-

\footnotetext{
${ }^{3}$ An MP ("Medida Provisória", or Provisional Measure) is a legal act that can be put forward by the Brazilian Executive Branch for "critical matters and at exceptional times", so as to enact laws effective for a maximum of 60 days without approval by Congress. MPs can be renewed for an additional 60 days, and Congress may amend, refute or accept MPs within 120 days (Provisional Measures: understanding the allegedly peculiar Brazilian legislative instrument).

${ }^{4} \mathrm{CNAE}$ is the National Classification of Economic Activities, which is the official classification used by federal institutions in Brazil, with 5 different levels of coverage (21 sections, including 87 2-digit divisions, 285 3-digit groups, 673 5-digit classes and 1301 7-digit sub-classes). The CNAE classification is derived from the International Standard Industrial Classification of All Economic Activities (ISIC), managed by the UN. The NCM is based on the Harmonized Commodity Description and Coding System developed by the World Customs Organization (WCO), and uses 8-digit product identifiers.
} 
tory when the policy was put in place, by the end of 2015 the government announced that participation in the tax policy would become optional. That is, in the beginning of each year, firms would be able to choose whether to contribute through the payroll tax of $20 \%$, or through the gross revenue tax. In MPs put forward in 2017 and 2018, the government also reduced significantly the number of sectors contemplated by the policy, meaning to reduce the loss of tax revenues it imposed. Therefore, I restrict my analysis to the years 2012 to 2015 , where adherence to the change in contribution was not optional and the coverage in sectors was at its largest.

Table 2.1 details all of the provisory measures and laws enacted between 2011 and 2015, which is the period of analysis in this paper. The initial announcement in 2011 included only two service sectors and four industries ${ }^{5}$ and in the beginning of 2012 the government announced a new set of sectors to be contemplated starting in August 2012, bringing the total to $15^{6}$. Finally, from the end of 2012 until 2014 the government put in place four additional MPs that increased the number of sectors subjected to the tax change to $42^{7}$. However, some sectors and products included by the MPs were later discarded or vetoed when the bills were passed through Congress, leading the firms contemplated in these MPs to have only momentary inclusion in the reform. Since the analysis here focuses on yearly data, I will take into account only the sectors and products that were included through laws passed by Congress.

Most of the research that has aimed to study the effects of the payroll tax reform implemented by PBM has focused exclusively on firms contemplated through the CNAE sectors list ${ }^{8}$. Yet the sectors which included the NCM products represented a significant portion of the Brazilian labor market. One of the main contributions of this paper is to include in the analysis sectors

${ }^{5}$ These were: firms that provided IT (information technology) and ITC (information technology and communications) services; and the textile, garment, leather and shoe industries.

${ }^{6}$ The new sectors added in 2012 were: firms that provided call center and design house services, and hotels; furniture, plastics, electric material and auto parts industries, as well as bus, naval and aeronautics industries, and mechanical capital goods.

${ }^{7}$ The new sectors included by these acts that were subjected to the $2 \%$ revenue tax were: firms that provided public road transport and construction companies. The new products and services included that were subject to the $1 \%$ revenue tax were: birds, swines and derivatives; fish; bread and pasta products; pharmaceuticals and medications; medical and dental equipment; bicycles; tires and air chambers; paper and cellulose; glass; stoves, refrigerators and washing machines; ceramics; ornamental rocks and stones; paints and varnishes; metallic construction; railway equipment; tools; steel products; nails, bolts and drawn steel wires; toys; optical instruments; airplane maintenance and repair; aerial and maritime transport; department stores and retail commerce.

${ }^{8}$ An exception is Narita et al. (2020), who run robustness exercises on their main regressions using the 5-digit CNAE sectors which included the NCM products listed in the payroll tax reform. They find no evidence that the reform impacted employment in these sectors, although they do not look at the reform's effect on wages through NCM lists. 
Table 2.1: MPs and legislation of the payroll tax reform

\begin{tabular}{lccccc}
\hline Legislation & Promulgation & Effective date & NCM & CNAE & Details \\
\hline MP 540 & Aug 2011 & Dec 2011 & 381 & 5 & Base for Law 12.546 \\
Law 12.546 & Dec 2011 & Apr 2012 & 62 & 6 & \\
MP 563 & Apr 2012 & Aug 2012 & 2379 & 1 & Base for Law 12.715 \\
Law 12.715 & Sep 2012 & Sep 2012 & 3325 & 15 & \\
MP 582 & Sep 2012 & Jan 2013 & 897 & & Base for Law 12.794 \\
Law 12.794 & Jan 2013 & Apr 2013 & 1009 & & \\
MP 601 & Dec 2012 & Apr 2013 & 70 & 23 & Expired \\
MP 612 & Apr 2013 & Aug 2013 & 27 & 33 & Expired \\
Law 12.844 & Jul 2013 & Nov 2013 & 90 & 83 & Based on MP 610 \\
\hline
\end{tabular}

Notes: Column NCM reports the number of 8-digit product identifiers included in that measure. Column CNAE reports the number of 5 -digit and 7 -digit sector identifiers listed by that measure.

a This MP did not include any sectors nor products to the payroll tax reform.

that were contemplated by the payroll tax reform through NCM products. By using IBGE's (Brazilian Institute of Geography and Statistics) dictionary for relating NCM product identifiers to CNAE sectors, it is possible to identify workers and firms in sectors which were affected by the reform through NCM lists.

Table 2.2 shows the percentage of production and sales values ${ }^{9}$ in the CNAE sectors that are represented by the NCM products included in the reform ${ }^{10}$. Overall, firms who manufacture any of the NCM products included in the first five years of the reform represent around $42 \%$ of the total production and sales of the sectors which include those NCM products. Although this may not imply that these firms represent equally as much in those sectors' employment, excluding them altogether may lead to understating the impact of the reform.

A useful analysis to understand the contribution of including sectors contemplated by the reform through NCM products is precisely to consider how the exclusion of this list affects the sample of workers. First, if we restrict the sample of workers only to sectors which covered firms included through the CNAE list (and none through the NCM list), this sample would represent $64.6 \%$ of total contracts - whereas including both allows for the use of the entirety of the data. Restricted to this sample, the share of contracts affected by the reform would represent $23.6 \%$ of the observations. However, when including both treatments (and thus not restricting the sample of analysis) the share of workers affected by the policy is around $27 \%$. By decomposing

\footnotetext{
${ }^{9}$ Unfortunately, there are no data on labor market outcomes which are identified by NCM products.

${ }^{10}$ There are no intersections between sectors included through CNAE 5 or 7 -digit identifiers and sectors included through NCM identifiers.
} 
Table 2.2: Share of industry level outcomes from NCM products

\begin{tabular}{lccccc}
\hline & \multicolumn{2}{c}{ Production } & & \multicolumn{2}{c}{ Sales } \\
\cline { 2 - 3 } \cline { 6 - 6 } & $\mathrm{R} \$(\mathrm{mn})$ & $\%$ & & $\mathrm{R} \$(\mathrm{mn})$ & $\%$ \\
& $(1)$ & $(2)$ & & $(3)$ & $(4)$ \\
\hline Law 12.546 & 115.63 & 30.4 & & 106.00 & 32.0 \\
Law 12.715 & 928.67 & 51.4 & & 826.01 & 51.5 \\
Law 12.794 & 633.59 & 32.3 & & 543.80 & 32.2 \\
Law 12.844 & 177.75 & 27.3 & & 166.56 & 27.9 \\
\hline Mean & & 41.3 & & 41.5 \\
\hline
\end{tabular}

Notes: The table shows absolute values and percentages of the CNAE 5-digit sector Production or Sales are represented by the NCM products included in each of laws that enacted the payroll tax reform between 2011 and 2015.

Source: IBGE (2011)

this share, almost $12 \%$ of workers between 2012 and 2015 were registered to sectors included in the reform through NCM products, and $15 \%$ included through CNAE sectors. These numbers show that including product identifiers in the treatment variable allows for a much more comprehensive approach of the payroll tax reform.

Finally, it is essential to describe the full context of the PBM and possible confounders of the payroll tax reform within the analysis of the this paper. In particular, discerning the other policies included in the PBM is a necessary step to establish that treatment through the payroll tax reform is not capturing the effects of other PBM policies that were implemented simultaneously. The PBM implemented measures along three major scopes: those aimed at stimulating investment and innovation; those focused on foreign trade; and those aimed at protecting domestic markets and industries. The payroll tax reform was included in the former, along with three other policies ${ }^{11}$. The measures in the first two scopes were directed at improving the environment for investments 12 and improving the competitiveness of Brazilian exporters ${ }^{13}$, respectively. Altogether, these policies were either sector specific (such as the auto industry)

${ }^{11}$ These were: a new set of rules for the production and importation of inputs in the auto industry; new regulation for public purchases that improved competitiveness for domestic firms; harmonization of financing policies in public banks.

${ }^{12}$ For instance, by reducing taxes on capital goods and providing wider access to subsidized credit lines for specific capital-intensive sectors. In terms of innovation, an example is the increase in directed credit lines for innovation.

${ }^{13}$ For instance, the Reintegra program introduced the reimbursement to exporting firms relative to taxes collected through the production chain, so as to reduce the cost of production for exported goods. 
or generally applied to almost the entire universe of domestic firms (such as most of the credit line policies). It is also relevant to highlight that the payroll tax reform was one of the only measures to target the labor market almost directly ${ }^{14}$, and probably the only one that had any effect on wages. Consequently, it is unlikely that treating the payroll tax reform through sector identifiers will capture any secondary effects of other PBM policies on wages.

\section{1}

\section{The effects of the payroll tax reform}

Considering the significant discretionary level of the payroll tax reform, this policy was the focus of several studies aimed at evaluating its effects on wages and employment. Garcia et al. (2018) find close to no effects on either wages or employment for all sectors. However, Dallava (2014) finds some positive effects on both wages and employment in the IT and ITC sectors, and some positive effects on wages in call center firms - although she only considers the first few sectors included in the reform.

Scherer (2015), on the other hand, only considered the first sectors included in the policy, but found significant effects on both wages and employment. He estimates an increase in wages of around $2 \%$ in the policy's first year and a $20 \%$ increase in employment. Finally, Meyer et al. (2019) use quasiexperimental and structural approaches to evaluate the payroll tax reform. Their identification strategy is based on the fact that the policy did not apply to small firms that participated in the simplified tax regime, and they find evidence only of positive effects on wages and employment for smaller firms. Their structural approach is based on estimating the policy's effects on measures of market imperfection, and they find that the policy shock had small although still positive effects on employment.

\footnotetext{
${ }^{14}$ There were three other measures that may have had an impact on the labor market. First, the BNDES Qualificação Program provided access to credit for private institutions of technical and professionalizing education, thus aiming at increasing the supply of qualified workers. The other two were the regulation of public purchases and the harmonization of financing policies in public bank, both of which aimed to indirectly increase the demand for labor. While the regulation of public purchases was sector specific, and some of the sectors contemplated were also included in the payroll tax reform, it is unlikely this policy had any effect on offered wages. Moreover, these policies were only likely to affect firms that actively sought out to participate in public auctions or credit from public banks, whereas the payroll tax reform affected all firms in the included sectors.
} 


\section{3 \\ Data and Empirical Strategy}

In this section, I briefly describe the main sources of data and variables used. Then, I outline the theoretical framework and empirical strategy behind my analysis.

\section{1 \\ Data}

The data on labor market outcomes comes from the Brazilian Ministry of Economy's database on formal labor contracts, RAIS (Relação Anual de Informações Sociais). This is a matched employer-employee dataset to which firms must report once a year, and because the government uses this registry ${ }^{1}$ to check eligibility criteria for mandated benefit programs, firms have clear incentives to provide accurate information.

The dataset includes information on both workers and firms. Firm-level data include characteristics such as firm size, legal nature, sector identifiers and tax regime indicators. Worker-level data include characteristics such as age, sex, race and education level, as well as information on the contract-level - monthly average wage, tenure, hours worked, admission and separation dates, occupation, contract type and reason for separation. Initially, the sample for analysis is restricted to firms with more than 20 employees, and in order to better capture the effects of wages on separation I also exclude workers whose motives for ending their contract are either death or retirement ${ }^{2}$. Finally, the sample only includes workers registered under the Consolidated Labor Laws (CLT) regime ${ }^{3}$.

The first dataset used here is the complete contract-level data, in which one observation is one contract - that is, one worker and firm match in a given year - which contains more than 138 million observations, spread across 4 years $^{4}$. Using this dataset, I construct the indicators of separation

\footnotetext{
${ }^{1}$ The only formal workers not included in this data are interns and domestic workers.

${ }^{2}$ Table 4.8 presents robustness exercises to using other firm size cutoffs in the sample of analysis.

${ }^{3}$ This excludes workers who are either hired under temporary contracts, trainees, chief executive offices or statutory contracts.

${ }^{4}$ Due to computational limits, I use in the main analysis presented in Section 4 a stratified sample of this complete dataset. Appendix Table A.1 presents summary statistics for both
} 
and recruitment, to and from employment. An individual is considered to have separated (been recruited) to (from) employment if a contract for that same worker with a different firm is found within 3 months of the separation (recruitment).

The use of a longer period for job-to-job transitions stems from the specificity of the Brazilian labor market. In particular, the legislation on unemployment and severance benefits in Brazil has led to a rise in what labor economists have labeled "false agreements". These agreements happen when firms dismiss workers so that they may receive unemployment benefits and gain access to their Severance Indemnity Fund (FGTS) - and then rehire those workers after their benefits have ended. This type of agreement allows workers who have held contracts for at least 6 months to access these benefits as well as for firms to avoid higher severance payments ${ }^{5}$, and therefore creating a false dismissal (Gonzaga and Pinto, 2014). Since unemployment benefits are limited to 3 months if workers have held their previous job for less than one year, this also leads to a sharp increase in rehiring at this 3-month mark after separations ${ }^{6}$. As such, recruitments and separations are only identified in the data if the transition occurs between different firms. If a worker does not transition to (from) another job within 3 months, then this is identified as a separation (recruitment) to (from) unemployment.

The second dataset used is a collapsed version of the contract-level data, in which each observation is a firm-year. I build firm-level variables based on separations and recruitments at the contract level, using the sample restrictions described by Bassier et al. (2020). These variables are defined as: the share of employees separating to employment out of all employees under continuous employment; the share of employees separating to unemployment out of all employees who did not have an outside option for job-to-job transition ${ }^{7}$; and the share of new hires who have come from employment.

Finally, I build as a treatment variable an indicator of whether a worker's

the full sample of 138 million observations in comparison to statistics for the sample used in the main analysis, with over 13 million observations. The sample is closely representative of the full data.

${ }^{5}$ Brazilian labor laws determine that separations taking place before a contract has completed a full year are only subject to both parties signing a dismissal agreement. Therefore, if a dismissal is of common agreement between employer and employee then the worker can agree to not receive the severance payment as long as he will gain access to the unemployment benefits and access to the severance fund.

${ }^{6}$ There are also reports of employees requesting employers to postpone their official hiring until they have been able to withdraw all of the installments of unemployment benefits they are entitled too, again contributing to this bunching of rehiring at the 3-month mark after separations.

${ }^{7}$ That is, either employees who held continuous employment at that firm or employees who separated to unemployment. 
contract (or a firm) in a particular year is reported under a sector that has been included in the payroll tax reform in that year or before ${ }^{8}$. For instance, if a firm belongs to a 5-digit CNAE sector included in the reform through legislation that was implemented in 2013, the treatment variable will be equal to zero for that firm in 2012, and equal to one in 2013 and in all subsequent years. It is important to note that for 5-digit CNAE sectors treated through the NCM lists, the treatment is an ITT (intent to treat), for two reasons. First, not all the products within that sector were included in the reform, and secondly firms were only partially affected depending on the share of revenue originating from the included products.

Table 3.1 presents some summary statistics with respect to firms and workers, and shows statistics for those who were included in the payroll tax reform and those who were not ${ }^{9}$. Columns (1) and (2) correspond to the full sample, while columns (3) and (4) correspond to the workers and firms which were not included in the reform. Columns (5) and (6) present statistics on firms and workers included through the CNAE lists, and columns (7) and (8) to those included through both CNAE and NCM lists ${ }^{10}$. Firms from the treated groups are on average considerably larger than in the full sample, and even more so than the control group. This is most likely a result of the reform excluding firms that contribute through the simplified corporate tax regime, which are exclusively small and medium firms (see Section 2). However, the measures of relative turnover at the firm level (share of employees either separating to other jobs or being recruited from other jobs) are similar across all samples.

Urbanization and informality data. For data on urbanization and informality I use the 2010 Brazilian Census (IBGE, 2010). I construct municipallevel statistics for both household and individual characteristics (reported in Appendix Table A.2). Two variables are used to separate the employeremployee data into sub-samples: (i) the share of households in urban areas and (ii) the share of individuals who report working in the informal sector, for a given municipality. This data is merged with the RAIS dataset through 6-digit municipality identifiers ${ }^{11}$. Appendix Figures A.2 and A.3 present the geographical distribution of these variables at the micro-region level ${ }^{12}$.

\footnotetext{
${ }^{8}$ Treatment variables are created separately if the sector was included through CNAE sector identifiers or NCM product identifiers.

${ }^{9}$ The data used for Table 3.1 is restricted to firms with at least 20 employees.

${ }^{10}$ Appendix Figure A.1 presents the share of worker-firm-year and firm-year observations treated with both CNAE and NCM lists by micro-region.

${ }^{11} \mathrm{It}$ is relevant to note that there is no concern for the endogeneity of these measures in what relates to the elasticity estimates, since the Census data was collected in 2010 and the main dataset spans the years 2012 to 2015.

${ }^{12}$ By comparing these figures with Appendix Figure A.1, there appears to be no correlation between whether a given region was more or less affected by the reform and its urbanization
} 
Table 3.1: Summary statistics

\begin{tabular}{|c|c|c|c|c|c|c|c|}
\hline \multicolumn{2}{|c|}{ Full sample } & \multicolumn{2}{|c|}{ Control } & \multicolumn{2}{|c|}{ CNAE treated } & \multicolumn{2}{|c|}{ Both treated } \\
\hline $\begin{array}{c}\text { Mean } \\
(1)\end{array}$ & $\begin{array}{l}\text { SD } \\
(2)\end{array}$ & $\begin{array}{c}\text { Mean } \\
(3)\end{array}$ & $\begin{array}{l}\text { SD } \\
(4)\end{array}$ & $\begin{array}{c}\text { Mean } \\
(5)\end{array}$ & $\begin{array}{l}\text { SD } \\
(6)\end{array}$ & $\begin{array}{c}\text { Mean } \\
(7)\end{array}$ & $\begin{array}{l}\text { SD } \\
(8)\end{array}$ \\
\hline
\end{tabular}

A. Contract-level statistics

\begin{tabular}{|c|c|c|c|c|c|c|c|c|}
\hline Monthly Wage (R\$) & 1650 & 2327 & 1600 & 2347 & 1669 & 2183 & 1742 & 2285 \\
\hline Gender $^{\mathrm{a}}$ & 0.65 & 0.48 & 0.62 & 0.48 & 0.74 & 0.44 & 0.71 & 0.45 \\
\hline Education ${ }^{\mathrm{b}}$ & 6.33 & 1.74 & 6.38 & 1.75 & 6.21 & 1.78 & 6.25 & 1.73 \\
\hline Age & 33.79 & 10.77 & 33.90 & 10.83 & 33.89 & 10.98 & 33.60 & 10.67 \\
\hline Tenure (months) & 33.05 & 53.52 & 31.93 & 52.94 & 26.06 & 44.69 & 35.13 & 54.54 \\
\hline$\%$ E-E Separations & 0.33 & & 0.33 & & 0.33 & & 0.32 & \\
\hline$\%$ E-E Recruits & 0.25 & & 0.24 & & 0.27 & & 0.27 & \\
\hline \# Observations (mn) & 138.09 & & 89.77 & & 25.80 & & 48.32 & \\
\hline \multicolumn{9}{|l|}{ B. Firm-level statistics } \\
\hline \# Employees & 123.51 & 450.64 & 109.59 & 416.29 & 197.61 & 692.30 & 178.03 & 562.11 \\
\hline \# Separations & 31.64 & 127.32 & 28.12 & 108.84 & 57.29 & 245.14 & 45.42 & 181.85 \\
\hline Recruits & 35.18 & 140.84 & 31.66 & 121.26 & 62.59 & 270.21 & 48.98 & 199.26 \\
\hline urnover rate $^{\mathrm{c}}(\%)$ & 25.61 & 28.25 & 25.65 & 26.14 & 28.99 & 35.40 & 25.51 & 32.35 \\
\hline E-E Separations & 0.09 & & 0.09 & & 0.11 & & 0.09 & \\
\hline , E-E Recruits & 0.27 & & 0.25 & & 0.30 & & 0.31 & \\
\hline Observations (thous) & 690.53 & & 550.06 & & 68.33 & & 140.47 & \\
\hline \multicolumn{9}{|c|}{$\begin{array}{l}\text { tes: This table shows summary statistics corresponding to the full data sets used throughout the analysis, both } \\
\text { ed on RAIS data for the period of } 2012-2015 \text {. Panel (a) presents contract-level statistics, and an observation in } \\
\text {; panel corresponds to a worker-firm-year. Panel (b) presents firm-level statistics created from the contract-level } \\
\text { a. An observation in this panel corresponds to a firm-year. } \\
\text { akes a value of } 1 \text { if individual is male. } \\
\text { akes values from } 1 \text { to } 11 \text {, corresponding to levels of education (for example, } 1 \text { indicates "illiterate", } 6 \text { indicates } \\
\text { sh school incomplete" and } 11 \text { indicates "PhD"). } \\
\text { urnover is defined as the share of employees that will leave employment in a given firm at a given year. }\end{array}$} \\
\hline
\end{tabular}

Table 3.2 reports contract-level statistics for each quartile of the distribution of both (i) and (ii) in the main dataset. As expected, workers from municipalities with lower urbanization are younger, less educated, and earn lower wages. Additionally, they have shorter tenure (in months) and transition less from job-to-job in the formal labor market - the latter could indicate the existence of fewer outside options, meaning workers are more likely to transition from or to unemployment than to or from other jobs. Moreover, workers from municipalities with smaller informal labor markets are more educated and earn higher wages. They also have longer tenure and transition more from job-to-job in the formal labor market. Again, the latter could reflect the fact that larger informal labor markets represent other outside options not capand informality rates. 
Table 3.2: Summary statistics for municipal share urban and informality quartiles

\begin{tabular}{|c|c|c|c|c|c|c|c|c|}
\hline & \multicolumn{2}{|c|}{$1^{\text {st }}$ Quartile } & \multicolumn{2}{|c|}{$2^{\text {nd }}$ Quartile } & \multicolumn{2}{|c|}{$3^{\text {rd }}$ Quartile } & \multicolumn{2}{|c|}{$4^{\text {th }}$ Quartile } \\
\hline & $\begin{array}{c}\text { Mean } \\
(1)\end{array}$ & $\begin{array}{l}\text { SD } \\
(2)\end{array}$ & $\begin{array}{c}\text { Mean } \\
(3)\end{array}$ & $\begin{array}{l}\text { SD } \\
(4)\end{array}$ & $\begin{array}{c}\text { Mean } \\
(5)\end{array}$ & $\begin{array}{l}\text { SD } \\
(6)\end{array}$ & $\begin{array}{c}\text { Mean } \\
(7)\end{array}$ & $\begin{array}{l}\text { SD } \\
(8)\end{array}$ \\
\hline \multicolumn{9}{|l|}{ A. \% Urban households } \\
\hline Wage $(\mathrm{R} \$)$ & 1200 & 1344 & 1394 & 1726 & 1697 & 2521 & 1564 & 2292 \\
\hline Gender $^{\mathrm{a}}$ & 0.66 & 0.47 & 0.62 & 0.48 & 0.61 & 0.49 & 0.61 & 0.49 \\
\hline Education ${ }^{\mathrm{b}}$ & 6.02 & 1.75 & 6.38 & 1.59 & 6.56 & 1.61 & 6.54 & 1.60 \\
\hline Age & 32.87 & 10.70 & 33.32 & 10.93 & 33.63 & 10.79 & 34.16 & 10.99 \\
\hline Tenure (months) & 29.67 & 45.80 & 29.63 & 47.80 & 30.64 & 48.64 & 31.60 & 53.23 \\
\hline \% E-E Separations & 0.26 & & 0.33 & & 0.32 & & 0.33 & \\
\hline$\%$ E-E Recruits & 0.17 & & 0.24 & & 0.23 & & 0.23 & \\
\hline \# Observations (mn) & 5.35 & & 5.43 & & 5.25 & & 5.32 & \\
\hline \multicolumn{9}{|l|}{ B. \% in Informality } \\
\hline Wage $(\mathrm{R} \$)$ & 1497 & 1789 & 1799 & 2742 & 1330 & 1650 & 1130 & 1292 \\
\hline Gender ${ }^{\mathrm{a}}$ & 0.61 & 0.49 & 0.60 & 0.49 & 0.64 & 0.48 & 0.66 & 0.47 \\
\hline Education $^{\mathrm{b}}$ & 6.39 & 1.63 & 6.56 & 1.63 & 6.35 & 1.62 & 6.15 & 1.69 \\
\hline Age & 33.49 & 11.09 & 33.90 & 10.99 & 33.60 & 10.84 & 32.88 & 10.50 \\
\hline Tenure (months) & 31.13 & 50.56 & 32.15 & 51.80 & 30.08 & 48.66 & 27.79 & 43.70 \\
\hline \% E-E Separations & 0.36 & & 0.34 & & 0.30 & & 0.24 & \\
\hline$\%$ E-E Recruits & 0.26 & & 0.24 & & 0.21 & & 0.16 & \\
\hline \# Observations (mn) & 4.72 & & 6.61 & & 4.71 & & 5.32 & \\
\hline
\end{tabular}

Notes: This table shows summary statistics on RAIS contract-level data for the period of 2012-2015. Each observation of the RAIS data is merged with municipal-level 2010 Census data, and subsequently separated into the quartiles of the municipal-level distribution of urbanization and informality rates. Panel (a) presents statistics on quartiles of the distribution of share of households in urban areas. Panel (b) presents statistics on quartiles of the distribution of share of share of individuals reporting working in informality.

tured by the administrative data - for instance the fact that workers are more likely to transition to or from unemployment in the formal labor market in municipalities with higher informality could just be capturing a higher likelihood that workers are transitioning between informal and formal jobs. Finally, workers in municipalities with higher informality are more likely to be women than in municipalities with lower informality. This most likely reflects the fact that women seek informality more often than men due to the flexibility that informal jobs offer to those who have a double workday (Malta et al., 2019; Berniell et al., 2021).

Skill data. To separate the employer-employee data into skill levels, I use the classification of the "Quadro Brasileiro de Qualificações" (QBQ), which is a database in development by the Brazilian Ministry of Economy that assigns occupations within the "Classificação Brasileira de Ocupações" (CBO) to 8 
skill levels described by the QBQ. The QBQ is inspired by the European Qualifications Framework (EQF), set up in 2008 by the European Union. One of its main goals is to provide a structure which relates to the necessary level of skill to perform a given occupation. As the EQF, the QBQ uses three distinct measures to determine the necessary skills of a given occupation, each with a score between 1 and 8. These measures are knowledge, ability and attitude, which in turn jointly determine a general measure of qualification between 1 and 8, with the latter being the most qualified (Brazilian Ministry of Economy, 2019).

Each level of the QBQ reflects a specific set of skills that describe a given occupation. For example, occupation code 324120 refers to radiology technicians whose summary of activities includes "operating and supervising the operations of radiology imagery equipment, preparing and accompanying patients during exams and fulfilling bio-safety protocols". This occupation received a score of 5 for knowledge, 5 for ability and 4 for attitude, with a general qualification score of 5. Appendix Table A.3 presents detailed descriptions of the respective qualifications capabilities associated to each level of the QBQ framework.

At the moment, the QBQ provides classification for 900 occupations, included in the large groups 3 through 9 of the $\mathrm{CBO}^{13}$. Large group 3 includes technicians with high school level knowledge, while large groups 4 to 9 encompass occupations in agriculture, industry, commerce and service sectors $^{14}$. For the current list of occupations provided by the Ministry of Economy, these encompass skill levels from 1 to 5 . This list is merged with the employer-employee dataset from RAIS through the occupational code provided by firms for each worker.

For the benefit of the analysis, I use both the five levels of skill provided by the QBQ as well as a broader definition based on the QBQ: low-skilled workers are those reported in either QBQ levels 1 or 2, while high-skilled workers are those reported in levels 4 or 5 . The statistics for these aggregate groups are presented in Table 3.3. As expected, workers in high skill occupations earn higher wages, are more educated, have longer tenure and are more likely to experience formal job-to-job transitions. Appendix Table A.4 reports summary statistics for the sub-sample of worker-firm-year observations recorded to each

\footnotetext{
${ }^{13}$ The data sample used in the main analysis of this paper includes workers in 1767 occupations from CBO large groups 3 to 9 . Nevertheless the 900 occupations listed in the QBQ represent over $86 \%$ of all worker-firm-year observations (including all CBO large groups).

${ }^{14}$ Large groups 0,1 and 2 include a diverse set of occupations, which typically vary from very highly skilled to low skilled. These have yet to be included in the QBQ classification.
} 
Table 3.3: Summary statistics by skill level

\begin{tabular}{lccccc} 
& \multicolumn{2}{c}{ Low } & & \multicolumn{2}{c}{ High } \\
\cline { 2 - 3 } & Mean & SD & & Mean & SD \\
& $(1)$ & $(2)$ & & $(3)$ & $(4)$ \\
\hline Wage $(\mathrm{R} \$)$ & 1127 & 987 & & 2578 & 2537 \\
Gender $^{\mathrm{a}}$ & 0.65 & 0.48 & & 0.64 & 0.48 \\
Education $^{\mathrm{b}}$ & 5.92 & 1.65 & & 7.36 & 1.24 \\
Age & 33.31 & 10.96 & & 34.60 & 9.91 \\
Tenure (months) & 26.32 & 43.85 & & 50.50 & 72.16 \\
\% E-E Separations & 0.32 & & & 0.36 & \\
\% E-E Recruits & 0.24 & & 0.29 & \\
\# Observations (mn) & 90.03 & & & 9.07 & \\
\hline
\end{tabular}

Notes: This table shows summary statistics on RAIS contractlevel data for the period of 2012-2015, and reports statistics for low-skill (QBQ levels 1 and 2) and high-skill (QBQ levels 4 and 5) workers.

level of qualification of the QBQ, and similar patterns can be observed for increased levels of qualification.

\section{2}

\section{Framework}

The theoretical framework presented here follows closely Manning (2003) and Manning (2011), which take on a turnover-based approach to estimating the labor supply wage elasticity. This framework is particularly useful in the Brazilian context since it allows for the estimation of labor supply wage elasticities using matched employer-employee data ${ }^{15}$. Assuming firms are represented by their average wage $w$, under steady state each firm will have its outflow of workers $S(w)$ equal to its inflow of workers $R(w)$. Given the supply of labor to that firm $N(w)$, the separation rate can be defined as $s(w)=\frac{S(w)}{N(w)}$, such that the steady state condition will be given by $N(w)=\frac{R(w)}{s(w)}$. Differentiating this condition with respect to $w$ we arrive at the core relation between the labor supply wage elasticity and recruitment and separation rate wage elasticities:

$$
\varepsilon_{N w}=\varepsilon_{R w}-\varepsilon_{s w}
$$

Given the cumulative distribution of wages in the labor market $F(w)$, with probability distribution $f(w)$, the separation rate and recruitment func-

\footnotetext{
${ }^{15}$ While a growing literature has attempted to use job posting or experimental data to estimate separation and recruitment elasticities separately (Azar et al., 2020, 2019; Dube et al., 2019, 2020), similar data for Brazil is not easily available and tends to be of limited scope.
} 
tions can be written as:

$$
\begin{gathered}
s(w)=\underbrace{\delta(w)}_{s^{u}(w)}+\underbrace{\lambda \cdot[1-F(w)]}_{s^{e}(w)} \\
R(w)=R^{u}(w)+\underbrace{\lambda \cdot \int_{0}^{w} f(x) \cdot N(x) d x}_{R^{e}(w)}
\end{gathered}
$$

where $\delta(w)$ indicates the exogenous probability of separating to unemployment, $\lambda$ is the arrival rate of job offers and $1-F(w)$ is the probability that the individual will accept that job offer ${ }^{16}$, while $R^{u}(w)$ represents recruitment from unemployment and $R^{e}(w)$, recruitment from employment. While Manning (2003) suggests using a simplifying assumption that both separation and recruitment to and from unemployment do not depend on the wage $w$, this may not be a realistic assumption in the case of the Brazilian labor market given its specificities (see Section 2), and would not change the results of this model.

Defining the share of transitions to and from employment as $\theta_{s}=\frac{s^{e}}{s^{e}+s^{u}}$ and $\theta_{R}=\frac{R^{e}}{R^{e}+R^{u}}$, we have that $R^{e}(w)=\theta_{R} \cdot R(w)$ and $s^{e}(w)=\theta_{s} \cdot s(w)$. By differentiating 3-2 and 3-3 with respect to $w$ and using the steady state condition, we arrive at the two main relationships between wage elasticities to and from employment:

$$
\begin{gathered}
\varepsilon_{R w}^{e}=-\frac{\theta_{s}}{\theta_{R}} \cdot \varepsilon_{s w}^{e} \\
\varepsilon_{R w}^{u}=\varepsilon_{R w}^{e}-\frac{\varepsilon_{\theta_{R}}}{1-\theta_{R}}
\end{gathered}
$$

Unlike Manning (2003) I do not use the simplifying assumption $\theta_{R}=\theta_{s}$, since the use of administrative data on formal contracts allows for the separate computation of these rates. Finally, the overall labor supply wage elasticity can be computed by:

$$
\varepsilon_{N w}=-\theta_{s} \cdot\left(\frac{1+\theta_{R}}{\theta_{R}}\right) \cdot \varepsilon_{s w}^{e}-\left(1-\theta_{s}\right) \cdot \varepsilon_{s w}^{u}-\varepsilon_{\theta_{R}}
$$

Thus, to estimate market level labor supply wage elasticity one needs estimates for $\varepsilon_{s w}^{e}, \varepsilon_{s w}^{u}$ and $\varepsilon_{\theta_{R}}$. Finally, the interpretation of $\varepsilon_{N w}$ comes from the relationship between labor supply and firms' profit maximizing behavior. Consider a given firm's profit maximizing problem:

\footnotetext{
${ }^{16}$ This specification implies that workers will only switch jobs if the job offer they receive offers a higher wage than the one they are currently earning, but this may not be realistic. Nevertheless, because the main analysis in this paper concerns firm-level observations, it is not so unrealistic to assume that workers will only switch jobs to firms with higher average wages than the average wage of the firm they are currently employed at. This assumption would be consistent with workers switching to lower wage jobs in expectation of higher earnings in the future in the firm they are switching to.
} 


$$
\begin{aligned}
\max _{w} \pi(w) & =p \cdot Y(N)-w \cdot N=p \cdot Y(N(w))-w \cdot N(w) \\
{[\mathrm{FOC}] \quad \frac{\partial}{\partial w} } & =\underbrace{p \cdot \frac{\partial Y(N)}{\partial N}}_{M R P_{N}} \cdot \frac{\partial N(w)}{\partial w}-w \cdot \frac{\partial N(w)}{\partial w}-N(w)=0 \\
& \Rightarrow \underbrace{\frac{M R P_{N}-w}{w}}_{\text {markdown on wages }}=\frac{N(w)}{\frac{\partial N(w)}{\partial w} \cdot w}=\frac{1}{\varepsilon_{N w}}
\end{aligned}
$$

That is, the inverse of the labor supply wage elasticity $\varepsilon_{N w}$ is equivalent to the measure of a firm's markdown on wages - which in turn reflects that firm's monopsony power in the labor market. Therefore, the closer $\varepsilon_{N w}$ is to zero, the more power firms exercise on the labor market, and the lower they set their wages compared to the marginal product of labor $\left(M R P_{N}\right)^{17}$. In the following Section 3.3 I discuss the empirical strategy adopted in this paper to estimate these elasticities.

Expected signs of recruitment and separation elasticities. Before describing the empirical strategy to estimate wage elasticities, it is important to discuss what we expect to see once these are estimated. In particular, what signs do we expect recruitment and separation wage elasticities to have?

In the case of separations, it is intuitive to assume that increases in offered wages would lead workers to become more selective of outside options. From the model, the definition of the separation rate to employment supports this assumption. Since $F(w)$ is increasing in $w$, with higher wages the separation rate $s^{e}(w)$ will decrease - that is, the probability that an individual worker will switch jobs will be lower. As such, we expect $\varepsilon_{s w}^{e}$ to be negative. In the case of separations to unemployment, since we consider $s^{u}(w)=\delta(w)$ to be an exogenous probability, the intuition is less clear. There are arguments to support it should be negative. For instance, if wages are increasing in characteristics that are positively correlated with better job stability (such as skill), then if an individual earns a higher wage the probability of separating into unemployment will be lower - and thus $\varepsilon_{s w}^{u}$ will also be negative.

In the case of recruitment from employment, Manning (2003) upholds the argument that higher wages lead to a higher $\theta_{R}$. The intuition for this reasoning is that if firms offer higher wages they are in a better position to poach workers from other firms - that is, recruit from employment. Again, the model's definition of the recruitment rate also supports this assumption. Since $f(w)$ and $N(w)$ are both non-negative, the rate of recruitment from

${ }^{17} \mathrm{~A}$ more direct interpretation is that if wages increase by $1 \%$, then the labor supply will increase by $\varepsilon_{N w} \%$. 
employment $R^{e}(w)$ will be increasing in $w$. Therefore, we expect $\varepsilon_{\theta_{R}}$ to be positive.

\section{3}

\section{Empirical Strategy}

The standard approach to estimate worker flows wage elasticities with a linear specification is the following:

$$
y_{i t}=\beta_{y} \cdot \log \left(w_{i t}\right)+\epsilon_{i t}
$$

where $y_{i t}$ is one of the separation or recruitment variables, and $w$ is the individual's wage. At the contract-level, the variable $y_{i t}$ takes a value of one if the worker-firm-year observation reflects one of the three transitions - job-tojob separation, job-to-unemployment separation and job-to-job recruitment. At the firm-level, $y_{i t}$ is the share of each transition to their respective firmlevel comparison samples, as described in Section 3.1. The resulting elasticity $\varepsilon_{y}$ is obtained by dividing the estimated coefficient by the sample mean.

However, estimating wage elasticities through worker flows encounters the classic issue of the endogeneity of wages. In Abowd et al. (1999)'s classic model of wage determination there are two time-invariant unobserved components of wages. The first is a worker component $\eta_{i}$, such as skill level, which is specific to each worker and which will help determine that individual's wage independently of which firm he works at. The second is a firm component $\phi_{f}$, which accounts for differences in wages between individuals with the same skill level. This firm specific factor can reflect firm-level wage policies or productivity determinants of wages, for instance. Furthermore, Card et al. (2018) introduces imperfect competition to this framework and finds evidence to support Abowd et al. (1999)'s hypothesis that wages are additively separable. Moreover, they show that firm characteristics are also significant in sorting more productive workers into more productive firms, and that therefore these characteristics (specifically TFP) are correlated with wage premiums. This interpretation of wage determination is useful to illustrate how both individual and firm characteristics can be correlated to separation and recruitment rates as well as wages.

In this respect, to accurately estimate these elasticities would require identifying the effects of wage variations on separation and recruitment rates independently from worker and firm level components. Here, the payroll tax reform implemented in Brazil by the PBM program can be a useful tool in precisely identifying shocks to wages that are independent from both workers and firms. Since the reform reflects a shock to the cost of hiring workers 
(that is, a shock to labor demand), the estimation strategy proposed here is to use the treatment variable from the reform as an instrument for wage variation. Although far from homogeneous, most studies carried out on PBM's payroll tax reform have found positive effects on wages, consistent with the interpretation that the reform reflected a shock to firms that shifted labor demand (as discussed in Section 2.1).

Therefore, the empirical strategy of this paper is to estimate Equation 3-10 using an IV approach, by instrumenting wages with payroll tax exemption shocks. The treatment variable $T_{i t}$ is defined as described in Section 3.1, and I report results including either only the CNAE sector identifiers (as was exclusively used in other studies of the payroll tax reform) or including both CNAE and NCM identifiers. This allows for the comparison between the results and provides support for the paper's argument that considering only the CNAE list may not fully capture the effects of the reform. Contractlevel specifications that include controls include worker characteristics such as gender, age, educational level, occupational code and average weekly hours; as well as firm characteristics such as firm size and 2-digit CNAE sector. Firmlevel specifications that include controls include characteristics such as firm size, 2-digit CNAE sector, average weekly hours of the firm's contracts, share of employees who are male and share of employees who identify as people of color. Specifications that include region fixed effects use macro-region identifiers ${ }^{18}$.

I follow the sample restrictions described by Bassier et al. (2020). First, to estimate the wage elasticity of separation to employment $\left(\varepsilon_{s w}^{e}\right)$ the sample includes only individuals who have been under continuous employment, so as to identify exclusively the effect that wage variation has on the individual decision of accepting an outside option. Second, to estimate the wage elasticity of separation to unemployment $\left(\varepsilon_{s w}^{u}\right)$ the goal is to identify the effect of wage variation on the decision to separate to unemployment, therefore the sample includes individuals who have either not separated or separated to unemployment (so as to exclude individuals who were faced with the outside option of separating to another job). Finally, to estimate the wage elasticity of being recruited from employment $\left(\varepsilon_{\theta_{R}}\right)$ the sample consists only of recruits, so as to identify the effect of wages on the probability that a recruit will come from another job.

Finally, the last strategy in this paper is to estimate labor supply wage

\footnotetext{
${ }^{18}$ Manning (2020) presents an interesting discussion on regional versus local markets and how using only geographical data to define labor markets may not be optimal. However, this discussion is more useful when guided towards estimating outcomes at the local labor market level. Since in the case of this paper we are only looking to control for possible common trends within local markets, using macro-regions should not be an issue.
} 
elasticities for different sub-samples of the data. In this case, equation 3-10 is estimated separately for each sub-sample. For instance, 3-10 is estimated separately for the sub-sample of workers from municipalities below the median of the share of urban households, and for the sub-sample that is above the median. Similarly, I estimate 3-10 for those above and below the median of share of informal workers in a given municipality, as well as different skill levels. All standard errors are clustered at the firm level.

Turnover versus stock-based approach. Previous work in the literature has used either a turnover or a stock-based approach to estimating labor supply wage elasticity. Sokolova and Sorensen (2021) describe this literature, contrasting both methodologies, and highlight that the stock-based approach has usually faced issues of endogeneity and provided estimates that are unrealistically low - typically below 2, implying markdowns of over $50 \%$. Additionally, Sokolova and Sorensen (2021) point out that the usefulness of a turnover-based approach arises precisely under the context of imperfect competition. To this respect, Manning (2003) builds on Burdett and Mortensen (1998)'s search model with frictions to present a simplification in the empirical strategy for estimating labor supply wage elasticities through worker-flows wage elasticities. I estimate as an initial exercise the labor supply wage elasticity for firms, $\varepsilon_{N w}$, using a stock based approach. To this end, I estimate the following:

$$
\log N_{f t}=\varepsilon \cdot w_{f t}+\epsilon_{f t}
$$

where $N_{f t}$ is firm $f$ 's labor supply (that is, total labor employed at that firm) in period $t$, and $w_{f t}$ is the wage paid to those workers. I identify $N_{f t}$ in the data as the number of individual workers reported employed by a given firm in a given year ${ }^{19}$, and $w_{f t}$ as the average wage for that given firm's contracts in that year.

Table 3.4 reports these results. Columns (1) to (3) present standard OLS estimates, while columns (4) to (6) present IV estimates as in the specification from the main results in Section 4. As expected, point estimates under OLS are low, and turn negative when the specifications include controls - as in columns (2) and (3). Under the IV estimates, the preferred specifications in columns (5) and (6) again are very low - around 0.5 - and indicate that the stock-based approach still carries considerable bias even when attempting to identify exogenous variation in wages through instrumentation. This may be a consequence of the structure of the data itself, since one observation in this

${ }^{19}$ This definition implies that if a worker settles a "false agreement" with their employer and is rehired later on in the year, this will be counted as only one unit of labor employed. 
Table 3.4: Stock-based labor supply wage elasticity

\begin{tabular}{|c|c|c|c|c|c|c|}
\hline & \multicolumn{6}{|c|}{ Dependent variable: $\log (\#$ Contracts $)$} \\
\hline & \multicolumn{3}{|c|}{ OLS } & \multicolumn{3}{|c|}{ IV: Both } \\
\hline & $(1)$ & $(2)$ & $(3)$ & $(4)$ & $(5)$ & $(6)$ \\
\hline $\log ($ Wage $)$ & $\begin{array}{c}0.23^{* * *} \\
(0.00)\end{array}$ & $\begin{array}{c}-0.02^{* * *} \\
(0.00)\end{array}$ & $\begin{array}{c}-0.02^{* * *} \\
(0.00)\end{array}$ & $\begin{array}{c}2.13^{* * *} \\
(0.03)\end{array}$ & $\begin{array}{c}0.51^{* * *} \\
(0.02)\end{array}$ & $\begin{array}{c}0.57^{* * *} \\
(0.02)\end{array}$ \\
\hline $\begin{array}{l}\text { Year + Region FE } \\
\text { Controls }\end{array}$ & & Yes & $\begin{array}{l}\text { Yes } \\
\text { Yes }\end{array}$ & & Yes & $\begin{array}{l}\text { Yes } \\
\text { Yes }\end{array}$ \\
\hline Observations (thous) & 690.53 & 681.16 & 681.16 & 690.53 & 681.16 & 681.16 \\
\hline R-Squared & 0.00 & 0.62 & 0.62 & 0.93 & 0.98 & 0.98 \\
\hline
\end{tabular}

Notes: Standard errors are reported in parenthesis and are clustered at the firm level.

analysis consists of yearly measures of labor supply and average wage at the firm level. That is, these observations reflect different equilibria that are prone to measurement error - particularly in the latter - due to the inconsistent timing of reported wages and contracts. Taken together, these results suggest that the use of a turnover-based approach is more fitting to the analysis at hand, especially given the nature of the data and of the payroll tax reform shock. 


\section{4 \\ Results}

This section presents the results of estimating Equation 3-10, both using standard OLS and the IV strategy described in Section 3.3, as well as the additional exercises of estimating the labor supply wage elasticity for different skill levels, and for municipalities' characteristics. I focus first on firm-level results - except in the analysis for skills levels - and present contract-level results along with robustness checks at the end of this section.

First stage and weak instrument test. Table 4.1 reports in the first two rows the first stage coefficients for the effect of both treatment variables (CNAE and NCM) on wages. For both contract and firm-level data, point estimates are positive, as expected. Panel (b) in Table 4.1 presents FStatistics for both instruments in the first stage regressions. Columns (4) to (6) show these statistics for the baseline firm-level data, which fall well above the standard threshold of 10 and indicate that the instruments are indeed relevant for explaining wage variation, even when including controls and fixed effects. Panel (c) reports the Cragg-Donald adjusted F-Statistics for testing whether the instruments are weak in the IV setting for all three workerflows variables (separation to employment, separation to unemployment and recruitment from employment). Estimates using firm-level data reported in columns (4) to (6) support the hypothesis that the payroll tax reform treatment variable is exogenous, under all specifications. Columns (1) to (3) present these same statistics using contract-level data. Although the F-Statistics in Panel (b) are only slightly above the 10 threshold, it is not unreasonable to assume the treatment variables are still relevant to identify exogenous variation in wages at the contract level.

Baseline estimates. For the results using firm-level data, Table 4.2 reports these estimates. The OLS elasticity estimates reported in columns (1) and (2) are considerably small, and would imply markdowns of over $100 \%$. The estimates in columns (3) to (5) - which use only treatment effects from CNAE lists - are negative, indicating that including only this treatment does not properly identify wage variation to estimate separation elasticities. The estimates using both CNAE and NCM lists reported in columns (6) to (8) are close to existing estimates of firm-level wage elasticities, when either controls 
Table 4.1: First stage \& Weak instrument test

\begin{tabular}{|c|c|c|c|c|c|c|}
\hline & \multicolumn{3}{|c|}{ Contract-level } & \multicolumn{3}{|c|}{ Firm-level } \\
\hline & $(1)$ & $(2)$ & $(3)$ & $(4)$ & $(5)$ & $(6)$ \\
\hline \multicolumn{7}{|c|}{ A. Dependent variable: $\log$ (Wage) } \\
\hline CNAE Treated & $\begin{array}{c}0.08 \\
(0.02)\end{array}$ & $\begin{array}{c}0.05 \\
(0.02)\end{array}$ & $\begin{array}{c}0.05 \\
(0.02)\end{array}$ & $\begin{array}{c}0.19 \\
(0.00)\end{array}$ & $\begin{array}{c}0.13 \\
(0.00)\end{array}$ & $\begin{array}{c}0.12 \\
(0.00)\end{array}$ \\
\hline NCM Treated & $\begin{array}{c}0.15 \\
(0.02)\end{array}$ & $\begin{array}{c}0.04 \\
(0.02)\end{array}$ & $\begin{array}{c}0.05 \\
(0.02)\end{array}$ & $\begin{array}{c}0.19 \\
(0.00)\end{array}$ & $\begin{array}{c}0.18 \\
(0.00)\end{array}$ & $\begin{array}{c}0.18 \\
(0.00)\end{array}$ \\
\hline \multicolumn{7}{|l|}{ B. F-Statistic } \\
\hline Both Treated & $\begin{array}{c}35.88 \\
(0.00)\end{array}$ & $\begin{array}{l}16.53 \\
(0.00)\end{array}$ & $\begin{array}{l}16.97 \\
(0.00)\end{array}$ & $\begin{array}{c}5250.89 \\
(0.00)\end{array}$ & $\begin{array}{c}3303.81 \\
(0.00)\end{array}$ & $\begin{array}{c}3014.30 \\
(0.00)\end{array}$ \\
\hline Full model & & $\begin{array}{c}1506.77 \\
(0.00)\end{array}$ & $\begin{array}{c}1309.02 \\
(0.00)\end{array}$ & & $\begin{array}{c}6759.96 \\
(0.00)\end{array}$ & $\begin{array}{c}6281.40 \\
(0.00)\end{array}$ \\
\hline Observations (mn) & 13.77 & 12.82 & 12.82 & 0.69 & 0.68 & 0.68 \\
\hline R-Squared & 0.01 & 0.31 & 0.31 & 0.04 & 0.15 & 0.16 \\
\hline \multicolumn{7}{|c|}{ C. Cragg-Donald F-Statistic } \\
\hline E-E Separations & $\begin{array}{c}73628.53 \\
(0.00)\end{array}$ & $\begin{array}{c}12017.88 \\
(0.00)\end{array}$ & $\begin{array}{c}8788.31 \\
(0.00)\end{array}$ & $\begin{array}{c}30890.03 \\
(0.00)\end{array}$ & $\begin{array}{c}17941.01 \\
(0.00)\end{array}$ & $\begin{array}{c}16301.18 \\
(0.00)\end{array}$ \\
\hline E-N Separations & $\begin{array}{c}78073.55 \\
(0.00)\end{array}$ & $\begin{array}{c}13415.82 \\
(0.00)\end{array}$ & $\begin{array}{c}10398.62 \\
(0.00)\end{array}$ & $\begin{array}{c}30880.90 \\
(0.00)\end{array}$ & $\begin{array}{c}17933.21 \\
(0.00)\end{array}$ & $\begin{array}{c}16292.55 \\
(0.00)\end{array}$ \\
\hline E-E Recruits & $\begin{array}{c}30355.63 \\
(0.00)\end{array}$ & $\begin{array}{c}11504.28 \\
(0.00)\end{array}$ & $\begin{array}{c}10611.27 \\
(0.00)\end{array}$ & $\begin{array}{c}30572.87 \\
(0.00)\end{array}$ & $\begin{array}{c}17623.78 \\
(0.00)\end{array}$ & $\begin{array}{c}16057.63 \\
(0.00)\end{array}$ \\
\hline Year + Region FE & & & Yes & & & Yes \\
\hline Controls & & Yes & Yes & & Yes & Yes \\
\hline
\end{tabular}

Notes: Columns (1) to (3) present results using contract-level data, while columns (4) to (6) use firmlevel data. Panels (a) and (b) report estimates and statistics of the first stage analysis, which regresses $\log$ (Wage) on the treatment variables and controls. Panel (c) reports weak instrument tests for the IV specifications described in Section 3.3, where the dependent variables are the worker-flows in the left column. Critical values for the F-Statistics reported in Panel (c) are from Stock and Yogo (2002). Standard errors are reported in parentheses in Panel (a) and are clustered at the firm level. P-values are reported in parentheses in Panels (b) and (c). 
Table 4.2: Firm-level labor supply wage elasticity

\begin{tabular}{|c|c|c|c|c|c|c|c|c|}
\hline & \multicolumn{2}{|c|}{ OLS } & \multicolumn{6}{|c|}{ IV } \\
\hline & (1) & $(2)$ & $(3)$ & (4) & (5) & (6) & $(7)$ & (8) \\
\hline E-E Separation $\varepsilon_{s w}^{e}$ & -0.18 & -0.35 & 1.52 & 1.86 & 2.46 & -0.80 & -2.28 & -2.27 \\
\hline E-N Separation $\varepsilon_{s w}^{u}$ & -0.42 & -0.46 & 0.81 & 1.25 & 1.34 & -0.83 & -1.45 & -1.47 \\
\hline E-E Recruitment $\varepsilon_{\theta_{R}}$ & 0.59 & 0.45 & 1.23 & 1.19 & 1.34 & 0.86 & 0.30 & 0.31 \\
\hline$\%$ E-E Separations & 0.33 & 0.33 & 0.33 & 0.33 & 0.33 & 0.33 & 0.33 & 0.33 \\
\hline$\%$ E-E Recruits & 0.25 & 0.25 & 0.25 & 0.25 & 0.25 & 0.25 & 0.25 & 0.25 \\
\hline Labor supply $\varepsilon_{N w}$ & $\begin{array}{c}0.00 \\
(0.01)\end{array}$ & $\begin{array}{c}0.44 \\
(0.01)\end{array}$ & $\begin{array}{l}-4.30 \\
(0.12)\end{array}$ & $\begin{array}{l}-5.10 \\
(0.20)\end{array}$ & $\begin{array}{l}-6.32 \\
(0.25)\end{array}$ & $\begin{array}{c}1.02 \\
(0.08)\end{array}$ & $\begin{array}{c}4.45 \\
(0.16)\end{array}$ & $\begin{array}{c}4.44 \\
(0.16)\end{array}$ \\
\hline Year + Region FE & & Yes & & & Yes & & & Yes \\
\hline Controls & & Yes & & Yes & Yes & & Yes & Yes \\
\hline IV Group & & & CNAE & CNAE & CNAE & Both & Both & Both \\
\hline \multicolumn{9}{|l|}{ Observations (thous) } \\
\hline E-E Separation & 690.45 & 681.09 & 690.45 & 681.09 & 681.09 & 690.45 & 681.09 & 681.09 \\
\hline E-N Separation & 690.50 & 681.14 & 690.50 & 681.14 & 681.14 & 690.50 & 681.14 & 681.14 \\
\hline E-E Recruitment & 670.61 & 661.57 & 670.61 & 661.57 & 661.57 & 670.61 & 661.57 & 661.57 \\
\hline
\end{tabular}

.

Notes: Columns (3) to (5) use only sectors included in the payroll tax reform through the CNAE list in the IV treatment variable. Columns (6) to (8) use sectors included through both CNAE and NCM lists in the IV treatment variable. Standard errors are reported in parenthesis and are clustered at the firm level.

or fixed effects or both are included. The preferred specification in column (8) would imply a markdown on wages of $22 \%$, which is close to existing estimates for developed countries (Azar et al., 2019; Dube et al., 2019) however relatively higher than existing estimates for the Brazilian labor market (Lagos, 2020; Vick, 2017).

It is also worth noting that the signs of the wage elasticities estimated in the preferred specifications are in accordance with what was described in Section 3.2: both separation elasticities are negative and the recruitment from employment elasticity is positive. In particular, as shown in Appendix Table A.4, wages and tenure are both increasing in skill which supports the argument that $\varepsilon_{s w}^{u}$ would be negative - and it is precisely what I find. The positive estimates for separation elasticities in columns (3) to (5) of Table 4.2 indicate that using only the CNAE sectors is probably not correctly identifying the effect of wage variation on separations ${ }^{1}$.

\footnotetext{
${ }^{1}$ Narita et al. (2020) use only the CNAE list and as such restrict their sample to include only 2-digit CNAE sectors where there was no inclusion into the reform through the NCM list. The estimates presented in columns (3) to (5) of Tables 4.5 and 4.2 use the full sample as in the full specification in columns (6) to (8) - that is contracts and firms that were affected by the reform through the NCM list are included in the control group. To rule out any issues in this specification, I run a robustness exercise on columns (3) to (5) by restricting the sample as in Narita et al. (2020). Appendix Table A.5 reports these results. For both contract and firm-level the separation elasticities' estimates are still positive and the final
} 
Moreover, the estimates for the wage elasticity of separation, which are all below -1, stand apart from existing estimates for Brazil - Tucker (2017) for example reports an estimate of -0.3. Given the characteristic of high turnover of the Brazilian labor market it is not unreasonable to expect a higher effect of wages on transitions, and the preferred estimates (between -1.1 and -2.2) would imply that wages do in fact have a more than one-to-one impact on separations.

Urbanization and informality. Table 4.3 reports estimates of labor supply wage elasticities for sub-samples of the firm-level data. Columns (1) and (2) report elasticity estimates for the sub-sample of firm-year observations in municipalities that fall respectively below and above the median share of individuals (in a given municipality) that report being employed in the informal sector. Workers from labor markets with less informality face firmlevel markdowns of $21 \%$ against $29 \%$ for workers in more informal markets. One way to interpret these results is that a larger relative presence of the informal sector translates to relatively fewer jobs in the formal sector. That is, there are fewer opportunities for workers to find formal jobs if informality is relatively larger, and therefore workers have less bargaining power in the formal labor market - in turn construed as higher oligopsony power for firms. Columns (3) and (4) of Table 4.3 report estimates for the sub-sample of firmyear observations in municipalities which fall respectively below and above the median share of urban households in a given municipality. These estimates imply that workers from rural labor markets face firm-level markdowns of $68 \%$ versus $18 \%$ for workers in urban labor markets. The results support existing evidence in the literature that more urbanized labor markets are correlated with higher competition among firms.

Skill. Finally, Table 4.4 reports labor supply wage elasticity estimates for different skill levels, using contract-level data. Columns (1) through (5) present estimates for each of the five skill levels from the QBQ present in the data, while columns (6) and (7) report estimates for aggregate definitions of low and high-skill workers, respectively. These estimates support the evidence from recent literature that low-skill workers face higher markdowns on wages than high-skill workers. While the results here are not as comprehensive of the data because very high skilled workers (QBQ levels 6 to 8) are not included, the estimates in columns (1) to (5) do provide insight into the pattern of labor market power exerted by firms for different skill levels. Comparing estimates from columns (1) and (5) (although these are a bit labor supply wage elasticity is still negative - although much closer to zero - thus indicating that sample selection is not driving the negative estimates reported in Tables 4.5 and 4.2. 
Table 4.3: Firm-level labor supply wage elasticity by urbanization and informality

\begin{tabular}{|c|c|c|c|}
\hline \multicolumn{2}{|c|}{$\%$ Informal } & \multicolumn{2}{|c|}{$\%$ Urban } \\
\hline $\begin{array}{c}\text { Below median } \\
\text { (1) }\end{array}$ & $\begin{array}{c}\text { Above median } \\
(2)\end{array}$ & $\begin{array}{c}\text { Below median } \\
(3)\end{array}$ & $\begin{array}{c}\text { Above median } \\
\text { (4) }\end{array}$ \\
\hline-2.12 & -2.05 & -1.10 & -2.50 \\
\hline-1.51 & -1.24 & -1.10 & -1.33 \\
\hline 0.17 & 0.80 & 1.08 & -0.36 \\
\hline 0.35 & 0.30 & 0.32 & 0.33 \\
\hline 0.27 & 0.22 & 0.25 & 0.25 \\
\hline $\begin{array}{c}4.84 \\
(0.17)\end{array}$ & $\begin{array}{c}3.44 \\
(0.34)\end{array}$ & $\begin{array}{c}1.46 \\
(0.21)\end{array}$ & $\begin{array}{c}5.43 \\
(0.17)\end{array}$ \\
\hline 352.10 & 328.98 & 340.27 & 340.81 \\
\hline 352.13 & 328.99 & 340.28 & 340.84 \\
\hline 342.50 & 319.06 & 330.71 & 330.85 \\
\hline
\end{tabular}

Notes: All columns use firm-level data and include controls for firm-year characteristics, including firm size, year, region, share of male employees, average weekly hours and share of employees which identify as people of color. Columns (1) and (3) present estimates for firm-year observations that fall below the median of municipal-level rates of informality and urbanization, respectively. Columns (2) and (4) present estimates for observations that fall above the median. Standard errors are reported in parenthesis and are clustered at the firm level.

noisy), low-skill workers would face a markdown of $60 \%$ against a markdown of $30 \%$ for high-skill workers. In particular, the results in columns (6) and (7) indicate that occupations which require supervision skills (QBQ levels 4 and 5) face considerably lower markdowns than occupations which are subject to supervision (QBQ levels 1 and 2) - 27\% versus 37\%, respectively.

Again, it is worth noting that the signs of all directly estimated wage elasticities in Tables 4.3 and 4.4, follow the expected signs described in Section 3.2 .

\section{1}

\section{Robustness exercises}

Contract-level data. Table 4.5 presents the results for the labor supply wage elasticity estimates using contract-level data. Columns (1) and (2) report the results of the standard OLS estimations, while columns (3) to (8) report estimates from the IV specifications. Overall, the OLS estimates are relatively low when compared to other estimates of labor supply wage elasticities for the Brazilian labor market and would imply an almost perfectly inelastic marketlevel labor supply. As for the IV specifications, estimates including only the CNAE treated sectors are negative - and not statistically significant. These estimates indicate that taking only this channel of the reform into account may 
Table 4.4: Labor supply wage elasticity by skill level

\begin{tabular}{lcccccccc} 
& \multicolumn{9}{c}{ QBQ Level } & & \multicolumn{2}{c}{ Skill Level } \\
\cline { 2 - 4 } & 1 & 2 & 3 & 4 & 5 & & Low & High \\
& $(1)$ & $(2)$ & $(3)$ & $(4)$ & $(5)$ & & $(6)$ & $(7)$ \\
\hline E-E Separation $\varepsilon_{s w}^{e}$ & -1.11 & -3.42 & -1.88 & -1.96 & -1.59 & -1.79 & -2.01 \\
E-N Separation $\varepsilon_{s w}^{u}$ & 0.20 & -0.42 & -0.19 & -1.18 & -0.85 & -1.20 & -0.50 \\
E-E Recruitment $\varepsilon_{\theta_{R}}$ & 0.08 & 2.08 & 0.77 & 0.45 & -0.27 & 0.63 & 0.44 \\
\% E-E Separations & 0.30 & 0.32 & 0.34 & 0.35 & 0.39 & & 0.32 & 0.36 \\
\% E-E Recruits & 0.21 & 0.25 & 0.29 & 0.28 & 0.32 & & 0.24 & 0.29 \\
Labor supply $\varepsilon_{N w}$ & 1.68 & 3.78 & 2.27 & 3.47 & 3.36 & 2.67 & 3.59 \\
& $(0.46)$ & $(3.27)$ & $(0.56)$ & $(0.56)$ & $(1.31)$ & $(0.69)$ & $(0.56)$ \\
\hline Observations $(m n)$ & & & & & & & \\
E-E Separation & 2.06 & 5.23 & 1.72 & 0.80 & 0.02 & & 7.29 & 0.81 \\
E-N Separation & 2.40 & 5.80 & 1.84 & 0.84 & 0.02 & & 8.20 & 0.86 \\
E-E Recruitment & 0.97 & 1.78 & 0.42 & 0.15 & 0.00 & & 2.75 & 0.15 \\
\hline
\end{tabular}

Notes: Columns (1) to (5) report estimates for the five levels of the QBQ, and columns (6) and (7) report statistics for low-skill (QBQ levels 1 and 2) and high-skill (QBQ levels 4 and 5) workers, respectively. All columns use contract-level data and include controls for workerfirm-year characteristics, including firm size, year, region, age, education and occupational level. Standard errors are reported in parenthesis and are clustered at the firm level.

be misleading. In particular, the positive estimates of the separation elasticities in columns (3) to (5) suggest that using only the CNAE treatment may lead to a weak identification of exogenous variation in wages. Columns (6) through (8) report the specifications which include both treatments, and these generate elasticity estimates much more in line with the existing literature (1.4 and 1.7). These estimates imply that an increase of $1 \%$ in wages would lead to a $1.7 \%$ increase in the labor supply.

Table 4.6 reports estimates of labor supply wage elasticities for subsamples of the contract-level data. While the point estimates are generally lower than those using firm-level data, the patterns remain the same. The results indicate that in labor markets where informality is more prevalent labor supply is more inelastic. The estimates imply that an increase of $1 \%$ in wages leads to a $2.8 \%$ increase in labor supply in more formalized labor markets, against a $1.3 \%$ increase in markets with a large informal sector ${ }^{2}$. As for the estimates relative to urbanization, the reported results imply that an increase of $1 \%$ in wages leads to an increase of $1.7 \%$ in the labor supply in rural labor markets versus $2.6 \%$ in urban labor markets. This indicates that labor supply

\footnotetext{
${ }^{2}$ These results seem to complement the findings of Ulyssea (2018). Taking from Ulyssea (2018)'s theoretical interpretations of informality, these estimates support the argument that in labor markets with high formality, a large part of informal workers do not enter formal jobs due to low productivity - that is, they are not "substitutes" for formal workers.
} 
Table 4.5: Contract-level labor supply wage elasticity

\begin{tabular}{|c|c|c|c|c|c|c|c|c|}
\hline & \multicolumn{2}{|c|}{ OLS } & \multicolumn{6}{|c|}{ IV } \\
\hline & (1) & $(2)$ & $(3)$ & (4) & $(5)$ & (6) & $(7)$ & $(8)$ \\
\hline E-E Separation $\varepsilon_{s w}^{e}$ & -0.46 & -0.42 & 5.41 & 26.57 & 20.05 & -1.15 & -1.09 & -1.15 \\
\hline E-N Separation $\varepsilon_{s w}^{u}$ & -0.57 & -0.52 & 4.78 & 41.28 & 22.78 & -0.54 & -1.20 & -1.46 \\
\hline E-E Recruitment $\varepsilon_{\theta_{R}}$ & 0.41 & 0.37 & 1.02 & 1.05 & 1.19 & 0.86 & 0.87 & 1.15 \\
\hline \% E-E Separations & 0.32 & 0.32 & 0.32 & 0.32 & 0.32 & 0.32 & 0.32 & 0.32 \\
\hline$\%$ E-E Recruits & 0.24 & 0.24 & 0.24 & 0.24 & 0.24 & 0.24 & 0.24 & 0.24 \\
\hline Labor supply $\varepsilon_{N w}$ & $\begin{array}{c}0.74 \\
(0.03)\end{array}$ & $\begin{array}{c}0.67 \\
(0.03)\end{array}$ & $\begin{array}{r}-13.11 \\
(6.55)\end{array}$ & $\begin{array}{c}-72.55 \\
(171.16)\end{array}$ & $\begin{array}{l}-49.46 \\
(71.04)\end{array}$ & $\begin{array}{c}1.38 \\
(0.40)\end{array}$ & $\begin{array}{c}1.73 \\
(0.94)\end{array}$ & $\begin{array}{c}1.73 \\
(1.17)\end{array}$ \\
\hline $\begin{array}{l}\text { Year }+ \text { Region FE } \\
\text { Controls } \\
\text { IV Group }\end{array}$ & & $\begin{array}{l}\text { Yes } \\
\text { Yes }\end{array}$ & $\mathrm{CNAE}$ & $\begin{array}{c}\text { Yes } \\
\text { CNAE }\end{array}$ & $\begin{array}{c}\text { Yes } \\
\text { Yes } \\
\text { CNAE }\end{array}$ & Both & $\begin{array}{c}\text { Yes } \\
\text { Both }\end{array}$ & $\begin{array}{l}\text { Yes } \\
\text { Yes } \\
\text { Both } \\
\end{array}$ \\
\hline \multicolumn{9}{|l|}{ Observations (mn) } \\
\hline E-E Separation & 11.53 & 11.53 & 11.53 & 11.53 & 11.53 & 11.53 & 11.53 & 11.53 \\
\hline E-N Separation & 12.72 & 12.72 & 12.72 & 12.72 & 12.72 & 12.72 & 12.72 & 12.72 \\
\hline E-E Recruitment & 3.65 & 3.65 & 3.65 & 3.65 & 3.65 & 3.65 & 3.65 & 3.65 \\
\hline
\end{tabular}

Notes: Columns (3) to (5) use only sectors included in the payroll tax reform through the CNAE list in the IV treatment variable. Columns (6) to (8) use sectors included through both CNAE and NCM lists in the IV treatment variable. Standard errors are reported in parenthesis and are clustered at the firm level.

is more elastic in more urban labor markets, in line with what the literature predicts.

Robustness checks. The baseline estimates presented above use the preferred sample restriction of firms with at least 20 employees and the transition cycle of up to 3 months, as well as the inclusion of controls and fixed effects. Additional exercises that compare estimates for different combinations of controls, different sample restrictions and transition cycles are reported in Tables 4.7 and 4.8. For contract-level estimates in Table 4.7's Panel (a), the inclusion of firm fixed effects significantly reduces point estimates, with little change to standard errors, leading to less accurate estimates. As for the firmlevel exercises in Panel (b), the inclusion of different fixed effects does not seem to impact point estimates significantly, with these remaining close to 4 .

Moreover, when using contract-level data, columns (1) to (5) of Table 4.8's Panel (a) show that point estimates are very sensitive to sample restriction. Columns (6) to (8) indicate that, nevertheless, estimates are not very sensitive to different definitions of transition cycles. The firm-level estimates presented in Panel (b) are much less sensitive to sample restrictions using firm size as well as different definitions of transition cycles. In particular, the estimates presented in columns (1) to (5) indicate that restricting the sample 
Table 4.6: Labor supply wage elasticity by urbanization and informality

$\%$ Informal

$\overline{\text { Below median } \text { Above median }}$

(1)

\begin{tabular}{lcccc}
\hline E-E Separation $\varepsilon_{s w}^{e}$ & -1.38 & -1.33 & -1.34 & -1.52 \\
E-N Separation $\varepsilon_{s w}^{u}$ & -0.98 & -0.10 & -0.52 & -0.59 \\
E-E Recruitment $\varepsilon_{\theta_{R}}$ & 0.09 & 0.86 & 0.86 & 0.33 \\
\% E-E Separations & 0.31 & 0.31 & 0.31 & 0.31 \\
\% E-E Recruits & 0.23 & 0.23 & 0.23 & 0.23 \\
Labor supply $\varepsilon_{N w}$ & 2.83 & 1.35 & 1.67 & 2.57 \\
& $(0.20)$ & $(0.67)$ & $(0.73)$ & $(0.40)$ \\
\hline Observations $(m n)$ & & & & \\
E-E Separation & 6.46 & 5.07 & 5.76 & 5.77 \\
E-N Separation & 7.02 & 5.70 & 6.39 & 6.33 \\
E-E Recruitment & 2.04 & 1.60 & 1.81 & 1.84 \\
\hline
\end{tabular}

Notes: All columns use contract-level data and include controls for worker-firm-year characteristics, including firm size, year, region, age, education and occupational level. Columns (1) and (3) present estimates for worker-firm-year observations that fall below the median of municipal-level rates of informality and urbanization, respectively. Columns (2) and (4) present estimates for observations that fall above the median. Standard errors are reported in parenthesis and are clustered at the firm level.

to larger firms generates much higher elasticity estimates. These results may reflect the well know firm size premium on wages (Alvarez et al., 2018; Colonnelli et al., 2018), wherein here the fact that larger firms pay higher wages inevitably implies they will exert lower markdowns.

Tables 4.9 and 4.10 report additional estimates for different quartiles of the distribution of the share of individuals working informally and share of households in urban areas, respectively. The point estimates provide the same intuition as the main results: firms' labor market power is increasing with the presence of informality and decreasing with urbanization. 
Table 4.7: Fixed effects robustness exercises

(1)

(2)

(3)

(4)

(5)

(6)

A. Contract-level estimates

E-E Separation $\varepsilon_{s w}^{e}$

E-N Separation $\varepsilon_{s w}^{u}$

E-E Recruitment $\varepsilon_{\theta_{R}}$

$-1.09$

$-1.19$

$-1.15$

$-0.73$

$-0.52$

$-0.59$

$-1.20$

$-1.59$

$-1.46$

$-0.91$

$-0.63$

$-1.20$

$\%$ E-E Separations

0.87

1.04

$1.15 \quad 0.88$

0.99

1.16

$\%$ E-E Recruits

0.32

0.32

0.32

0.32

0.32

0.32

0.24

0.24

0.24

0.24

0.24

0.24

Labor supply $\varepsilon_{N w}$

$1.73 \quad 2.00$

1.73

0.93

0.28

0.63

(0.94)

(1.12)

(1.17)

(0.88)

(0.84)

\section{B. Firm-level estimates}

\begin{tabular}{lcccccc} 
E-E Separation $\varepsilon_{s w}^{e}$ & -2.18 & -2.17 & -2.27 & -2.20 & -2.28 & -2.27 \\
E-N Separation $\varepsilon_{s w}^{u}$ & -1.41 & -1.43 & -1.47 & -1.37 & -1.40 & -1.42 \\
E-E Recruitment $\varepsilon_{\theta_{R}}$ & 0.36 & 0.36 & 0.31 & 0.36 & 0.31 & 0.32 \\
\% E-E Separations & 0.33 & 0.33 & 0.33 & 0.33 & 0.33 & 0.33 \\
\% E-E Recruits & 0.25 & 0.25 & 0.25 & 0.25 & 0.25 & 0.25 \\
Labor supply $\varepsilon_{N w}$ & 4.19 & 4.19 & 4.44 & 4.21 & 4.40 & 4.39 \\
& $(0.16)$ & $(0.16)$ & $(0.16)$ & $(0.18)$ & $(0.18)$ & $(0.18)$ \\
\hline Region FE & & & Yes & & Yes & Yes \\
Year FE & & Yes & Yes & & & Yes \\
Firm FE & & & & Yes & Yes & Yes \\
Controls & Yes & Yes & Yes & Yes & Yes & Yes \\
\hline
\end{tabular}

Notes: Columns (1) to (5) report estimates for different sample restrictions according to firm size. Columns (6) to (8) report estimates for different definitions of job-to-job transitions. Transition equal to zero indicates a transition is made in the same month, one indicates a transition can occur within one month, and three indicates a transition can occur within three months. All columns include controls for worker-firm-year and firm-year characteristics, including firm size, year, and region. Panel (a) also includes age, education and occupational level, while Panel (b) includes average weekly hours, share of employees who identify as people of color, and share of male employees. Standard errors are reported in parenthesis and are clustered at the firm level. 
Table 4.8: Robustness exercises for firm size and transition cycle

By firm size

By transition

$\begin{array}{llllllll}(1) & (2) & (3) & (4) & (5) & (6) & (7) & (8)\end{array}$

\begin{tabular}{|c|c|c|c|c|c|c|c|c|}
\hline \multicolumn{9}{|c|}{ A. Contract-level estimates } \\
\hline E-E Separation $\varepsilon_{s w}^{e}$ & 0.14 & -0.65 & -1.15 & -2.27 & -5.47 & -0.59 & -0.96 & -1.15 \\
\hline E-N Separation $\varepsilon_{s w}^{\text {sw }}$ & -0.14 & -0.86 & -1.46 & -2.98 & -5.73 & -1.23 & -1.39 & -1.46 \\
\hline E-E Recruitment $\varepsilon_{\theta_{R}}$ & 1.14 & 1.15 & 1.15 & 1.15 & 1.10 & 0.69 & 0.83 & 1.15 \\
\hline \% E-E Separations & 0.31 & 0.32 & 0.32 & 0.32 & 0.33 & 0.10 & 0.20 & 0.32 \\
\hline$\%$ E-E Recruits & 0.22 & 0.24 & 0.25 & 0.25 & 0.07 & & & \\
\hline Labor supply $\varepsilon_{N w}$ & $\begin{array}{l}-1.27 \\
(0.66)\end{array}$ & $\begin{array}{c}0.51 \\
(0.68)\end{array}$ & $\begin{array}{c}1.73 \\
(1.17)\end{array}$ & $\begin{array}{c}4.54 \\
(4.09)\end{array}$ & $\begin{array}{c}11.55 \\
(18.96)\end{array}$ & $\begin{array}{c}1.27 \\
(1.50)\end{array}$ & $\begin{array}{c}1.73 \\
(1.23)\end{array}$ & $\begin{array}{c}1.73 \\
(1.17)\end{array}$ \\
\hline \multicolumn{9}{|l|}{ Observations ( $m n$ ) } \\
\hline $\mathrm{E}-\mathrm{E}$ & .27 & 3.69 & 11.53 & 8.82 & 7.02 & 10.79 & 11.15 & 11.53 \\
\hline $\mathrm{E}-\mathrm{N} s$ & 19.23 & 15.14 & 12.72 & 9.68 & 7.68 & 13.46 & 13.10 & 12.72 \\
\hline E-E Recru & 5.59 & 4.38 & 3.65 & 2.71 & 2.09 & 3.65 & 3.65 & 3.65 \\
\hline \multicolumn{9}{|c|}{ B. Firm-level estimates } \\
\hline E-E Separation $\varepsilon_{s w}^{e}$ & -1.85 & -1.89 & -2.27 & -3.04 & -3.25 & -3.11 & -2.57 & -2.27 \\
\hline E-N Separ & -1.21 & -1.23 & -1.47 & -1.89 & -1.87 & -1.45 & -1.44 & -1.47 \\
\hline E-E Recruitment $\varepsilon_{\theta_{R}}$ & 0.67 & 0.45 & 0.31 & 0.06 & -0.07 & 0.74 & 0.44 & 0.31 \\
\hline \% E-E Separations & 0.32 & 0.33 & 0.33 & 0.34 & 0.34 & 0.10 & 0.21 & 0.33 \\
\hline$\%$ E-E Recruits & 0.23 & 0.24 & 0.25 & 0.26 & 0.26 & 0.07 & 0.16 & 0.25 \\
\hline Labor supply $\varepsilon_{N w}$ & $\begin{array}{c}3.32 \\
(0.15)\end{array}$ & $\begin{array}{c}3.55 \\
(0.13)\end{array}$ & $\begin{array}{c}4.44 \\
(0.16)\end{array}$ & $\begin{array}{l}6.18 \\
(028)\end{array}$ & $\begin{array}{c}6.62 \\
(0.39)\end{array}$ & $\begin{array}{c}5.06 \\
(0.24)\end{array}$ & $\begin{array}{c}4.65 \\
(0.19)\end{array}$ & $\begin{array}{c}4.44 \\
(0.16)\end{array}$ \\
\hline \multicolumn{9}{|l|}{ Observations (mn) } \\
\hline E-E S & 9.20 & 1.61 & 0.68 & 0.20 & 0.07 & 0.68 & 0.68 & 0.68 \\
\hline E-N S & 9.20 & 1.61 & 0.68 & 0.20 & 0.07 & 0.68 & 0.68 & 0.68 \\
\hline E-E Recruitment & 5.51 & 1.50 & 0.66 & 0.19 & 0.07 & 0.66 & 0.66 & 0.66 \\
\hline Firm & $0+$ & $10+$ & $20+$ & $50+$ & $100+$ & $20+$ & $20+$ & $20+$ \\
\hline Trans & 3 & 3 & 3 & 3 & 3 & 0 & 1 & 3 \\
\hline
\end{tabular}

Notes: All columns include controls for worker-firm-year and firm-year characteristics, including firm size, year, and region. Panel (a) also includes age, education and occupational level, while Panel (b) includes average weekly hours, share of employees who identify as people of color, and share of male employees. Standard errors are reported in parenthesis and are clustered at the firm level. 
Table 4.9: Robustness exercises by municipal-level rates of informality

Quartile

$1^{\text {st }} \quad 2^{\text {nd }} \quad 3^{\text {rd }} \quad 4^{\text {th }}$

(1) (2) (3) (4)

\begin{tabular}{lcccc}
\hline E-E Separation $\varepsilon_{s w}^{e}$ & -1.37 & -1.34 & -1.34 & -0.39 \\
E-N Separation $\varepsilon_{s w}^{u}$ & -1.10 & -0.87 & -0.65 & -0.54 \\
E-E Recruitment $\varepsilon_{\theta_{R}}$ & 0.09 & 0.05 & 0.47 & 0.55 \\
\% E-E Separations & 0.33 & 0.33 & 0.33 & 0.33 \\
\% E-E Recruits & 0.25 & 0.25 & 0.25 & 0.25 \\
Labor supply $\varepsilon_{N w}$ & 2.87 & 2.74 & 2.16 & 0.47 \\
& $(0.23)$ & $(0.25)$ & $(0.48)$ & $(0.05)$ \\
\hline Observations (mn) & & & & \\
E-E Separation & 2.60 & 3.86 & 2.23 & 2.84 \\
E-N Separation & 2.82 & 4.20 & 2.48 & 3.22 \\
E-E Recruitment & 0.84 & 1.21 & 0.69 & 0.91 \\
\hline
\end{tabular}

Notes: All columns use contract-level data and include controls for worker-firm-year characteristics, including firm size, year, region, age, education and occupational level. Standard errors are reported in parenthesis and are clustered at the firm level.

Table 4.10: Robustness exercises by municipal-level rates of urbanization

\begin{tabular}{lcccc} 
& \multicolumn{4}{c}{ Quartile } \\
\cline { 2 - 5 } & $1^{\text {st }}$ & $2^{\text {nd }}$ & $3^{\text {rd }}$ & $4^{\text {th }}$ \\
& $(1)$ & $(2)$ & $(3)$ & $(4)$ \\
\hline E-E Separation $\varepsilon_{s w}^{e}$ & -0.48 & -1.36 & -2.00 & -1.26 \\
E-N Separation $\varepsilon_{s w}^{u}$ & -0.60 & -0.91 & -0.85 & -0.45 \\
E-E Recruitment $\varepsilon_{\theta_{R}}$ & 0.53 & 0.66 & 0.40 & 0.29 \\
\% E-E Separations & 0.33 & 0.33 & 0.33 & 0.33 \\
\% E-E Recruits & 0.25 & 0.25 & 0.25 & 0.25 \\
Labor supply $\varepsilon_{N w}$ & 0.68 & 2.17 & 3.46 & 2.10 \\
& $(2.32)$ & $(0.45)$ & $(0.51)$ & $(0.49)$ \\
\hline Observations $(m n)$ & & & & \\
E-E Separation & 2.88 & 2.89 & 2.92 & 2.85 \\
E-N Separation & 3.23 & 3.16 & 3.21 & 3.12 \\
E-E Recruitment & 0.88 & 0.92 & 0.93 & 0.91 \\
\hline
\end{tabular}

Notes: All columns use contract-level data and include controls for worker-firm-year characteristics, including firm size, year, region, age, education and occupational level. Standard errors are reported in parenthesis and are clustered at the firm level. 


\section{5}

\section{Conclusion}

Understanding non-competitive behavior in labor markets has become a crucial aspect to gain insight into labor market dynamics, and estimating labor supply wage elasticities can help determine the existence of oligopsony power. Using matched employer-employee administrative data and a novel IV approach, this paper aims to estimate measures of labor market power and contribute to the understanding of oligopsony power by Brazilian firms. In particular, I use exogenous shocks through the extensive payroll tax reform implemented by the government since 2011 to instrument for the endogeneity of wages and cleanly identify labor supply wage elasticities.

The reported results indicate that firms do exercise a considerable amount of power in determining wages. Point estimates reveal a firm-level labor supply wage elasticity of 4.4. These would imply that firms exert markdowns on wages of around $20 \%$. I also find that labor supply wage elasticities are lower in rural labor markets and in labor markets where informality is more prominent, corroborating previous findings in the literature and providing further insight into Brazilian labor markets. Moreover, I look at differential elasticities between skill levels, and find that markdowns are higher for lowskilled workers, in line with what most of the literature predicts. These results indicate that most workers in Brazil earn well below their marginal product, as well that this seems to be considerably heterogeneous across various margins. Further research into the heterogeneity of these markdowns can provide further insights into labor market dynamics in Brazil.

One shortcoming of this research is that the treatment effect used from the payroll tax reform is an ITT that does not capture the intensity of the shock at the firm level, since we only observe whether a given firm belongs to a treated sector or not. Firm-level data on both revenues, payroll tax payments and share of revenues originating from treated NCM products could allow to identify more clearly to what degree a given firm was affected by the reform. Access to this data can provide a valuable extension to this paper. Finally, finding other ways to instrument for wages can also allow for estimating labor supply wage elasticities for larger periods of time and provide a better understanding of how labor market power in Brazil has progressed over time. 


\section{Bibliography}

ABDI (2014). Relatório de acompanhamento de medidas sistêmicas, plano brasil maior. Available at https://tinyurl.com/sdqcm6j. Accessed 18/03/2020.

Abel, W., Tenreyro, S., and Thwaites, G. (2018). Monopsony in the UK. CEPR Discussion Papers 13265, C.E.P.R. Discussion Papers.

Abowd, J., Kramarz, F., and Margolis, D. (1999). High wage workers and high wage firms. Econometrica, 67(2):251-334.

Alcaraz, C., Chiquiar, D., and Salcedo, A. (2015). Informality and segmentation in the Mexican labor market. Working Papers 2015-25, Banco de México, Ciudad de México.

Almeida, E., Araujo, V., and Gonçalves, S. (2020). Urban wage premium in a labor market with informality. SSRN Scholarly Paper ID 3721640, Social Science Research Network.

Alvarez, J., Benguria, F., Engbom, N., and Moser, C. (2018). Firms and the Decline in Earnings Inequality in Brazil. American Economic Journal: Macroeconomics, 10(1):149-89.

Azar, J., Berry, S., and Marinescu, I. E. (2019). Estimating labor market power. SSRN Scholarly Paper ID 3456277, Social Science Research Network, Rochester, NY.

Azar, J., Marinescu, I., Steinbaum, M., and Taska, B. (2020). Concentration in U.S. labor markets: Evidence from online vacancy data. Labour Economics, 66:101886.

Azar, J., Marinescu, I. E., and Steinbaum, M. (2017). Labor market concentration. IZA Discussion Papers 11254, Institute of Labor Economics (IZA).

Bachmann, R., Demir, G., and Frings, H. (2020). Labour Market Polarisation, Job Tasks and Monopsony Power. IZA Discussion Papers 13989, Institute of Labor Economics (IZA).

Banfi, S. and Villena-Roldán, B. (2019). Do High-Wage Jobs Attract More Applicants? Directed Search Evidence from the Online Labor Market. Journal of Labor Economics, 37(3):715-746. 
Bassier, I., Dube, A., and Naidu, S. (2020). Monopsony in movers: The elasticity of labor supply to firm wage policies. Working Paper 27755, National Bureau of Economic Research.

Baum-Snow, N. and Pavan, R. (2012). Understanding the city size wage gap. The Review of Economic Studies, 79(1):88-127.

Behrens, K., Duranton, G., and Robert-Nicoud, F. (2014). Productive cities: Sorting, selection, and agglomeration. Journal of Political Economy, 122(3):507553.

Benmelech, E., Bergman, N., and Kim, H. (2018). Strong Employers and Weak Employees: How Does Employer Concentration Affect Wages? NBER Working Papers 24307, National Bureau of Economic Research, Inc.

Berniell, I., Berniell, L., de la Mata, D., Edo, M., and Marchionni, M. (2021). Gender gaps in labor informality: The motherhood effect. Journal of Development Economics, 150:102599.

Bertranou, F., Casanova, L., Jiménez, M., and Jiménez, M. (2014). Informality and employment quality in Argentina: Country case study on labour market segmentation. ILO Working Papers, International Labour Organization.

Bó, E. D., Finan, F., and Rossi, M. A. (2013). Strengthening State Capabilities: The Role of Financial Incentives in the Call to Public Service. The Quarterly Journal of Economics, 128(3):1169-1218.

Bonanno, A. and Lopez, R. A. (2012). Wal-mart's monopsony power in metro and non-metro labor markets. Regional Science and Urban Economics, 42(4):569579.

Borjas, G. J. (2016). Labor Economics. McGraw-Hill Education, New York, 7th edition.

Brazilian Ministry of Economy (2019). Quadro Brasileiro de Qualificações (QBQ). Available at http://qbqconsulta.fipe.org.br/. Accessed on 13-02-2021.

Burdett, K. and Mortensen, D. (1998). Wage differentials, employer size, and unemployment. International Economic Review, 39(2):257-73.

Caldwell, S. and Oehlsen, E. (2018). Monopsony and the gender wage gap: Experimental evidence from the gig economy. Unpublished. 
Card, D., Cardoso, A. R., Heining, J., and Kline, P. (2018). Firms and Labor Market Inequality: Evidence and Some Theory. Journal of Labor Economics, 36(S1):S13 - S70.

Colonnelli, E., Tåg, J., Webb, M., and Wolter, S. (2018). A cross-country comparison of dynamics in the large firm wage premium. AEA Papers and Proceedings, 108:323-27.

Combes, P.-P., Duranton, G., Gobillon, L., and Roux, S. (2012). Sorting and local wage and skill distributions in France. Regional Science and Urban Economics, 42(6):913-930.

da Silva, A. F. R. E. and Pero, V. L. (2008). Segmentação do mercado de trabalho e mobilidade de renda entre 2002 e 2007. Anais do xxxvi encontro nacional de economia [proceedings of the 36th brazilian economics meeting], ANPEC Associação Nacional dos Centros de Pós-Graduação em Economia.

Dalberto, C. R. and Cirino, J. F. (2018). Informalidade e segmentação no mercado de trabalho brasileiro: Evidências quantílicas sob alocação endógena. Nova Economia, 28:417 - 460 .

Dallava, C. C. (2014). Impactos da Desoneração da Folha de Pagamentos Sobre o Nível de Emprego no Mercado de Trabalho Brasileiro: Um Estudo a Partir dos Dados da RAIS. Master's thesis, Escola de Economia de São Paulo, Fundação Getúlio Vargas, São Paulo.

Dauth, W., Findeisen, S., Moretti, E., and Suedekum, J. (2019). Matching in Cities. IZA Discussion Papers 12278, Institute of Labor Economics (IZA).

D'Costa, S. and Overman, H. (2014). The urban wage growth premium: Sorting or learning? Regional Science and Urban Economics, 48(C):168-179.

Dube, A., Giuliano, L., and Leonard, J. (2019). Fairness and Frictions: The Impact of Unequal Raises on Quit Behavior. American Economic Review, 109(2):620663.

Dube, A., Jacobs, J., Naidu, S., and Suri, S. (2020). Monopsony in Online Labor Markets. American Economic Review: Insights, 2(1):33-46.

Falch, T. (2010). The elasticity of labor supply at the establishment level. Journal of Labor Economics, 28(2):237-266.

Garcia, F., Sachsida, A., and de Carvalho, A. Y. (2018). Impacto da desoneração da folha de pagamento sobre o emprego: Novas evidências. Texto para discussão, Ipea. 
Gonzaga, G. and Pinto, R. C. (2014). Rotatividade do trabalho e incentivos da legislação trabalhista. Textos para discussão 625, Department of Economics PUC-Rio (Brazil).

Guerriero, M. (2019). The labor share of income around the world: Evidence from a panel dataset. In Fields, G. and Paul, S., editors, Labor Income Share in Asia: Conceptual Issues and the Drivers, pages 39-79. Springer Singapore, Singapore.

IBGE (2010). Censo demográfico. Available at https://ibge.gov . br/. Accessed on $10-02-2021$.

IBGE (2011). Pesquisa industrial anaual. Avaliable at https://ibge.gov.br/. Accessed on 4-11-2020.

Lagos, L. (2020). Labor Market Institutions and the Composition of Firm Compensation: Evidence from Brazilian Collective Bargaining. Job Market Paper.

Malta, V., Kolovich, L., Martinez, A., and Tavares, M. (2019). Informality and gender gaps going hand in hand. IMF Working Papers, 19:1.

Manning, A. (2003). Monopsony in Motion: Imperfect Competition in Labor Markets. Princeton University Press.

Manning, A. (2011). Imperfect competition in the labor market. In Ashenfelter, O. and Card, D., editors, Handbook of Labor Economics, volume 4B, chapter 11, pages 973-1041. Elsevier, 1st edition.

Manning, A. (2020). Monopsony in labor markets: A review. LSE Research Online Documents on Economics 103482, London School of Economics and Political Science, LSE Library.

Marinescu, I., Ouss, I., and Pape, L. (2020). Wages, Hires, and Labor Market Concentration. National Bureau of Economic Research.

Martins, P. (2018). Making their own weather? Estimating employer labour-market power and its wage effects. Working Papers 95, Queen Mary, University of London, School of Business and Management, Centre for Globalisation Research.

Matsudaira, J. D. (2014). Monopsony in the Low-Wage Labor Market? Evidence from Minimum Nurse Staffing Regulations. The Review of Economics and Statistics, 96(1):92-102. 
Meyer, L. G., de Lucinda, C. R., and Spolador, H. F. S. (2019). Structural Vs. Quasi-Experimental Policy Evaluation: The Payroll Tax Exemption in Brazil. In 47ํㅡㄹ Encontro Nacional de Economia. ANPEC, São Paulo.

Monteiro, J. C. and Assunção, J. J. (2012). Coming out of the shadows? Estimating the impact of bureaucracy simplification and tax cut on formality in Brazilian microenterprises. Journal of Development Economics, 99(1):105-115.

Narita, R., Baumgartner, E., and Corbi, R. (2020). Payroll tax, employment and labor market concentration. Working Paper.

Nisic, N. (2017). Smaller Differences in Bigger Cities? Assessing the Regional Dimension of the Gender Wage Gap. European Sociological Review, 33:292304.

Perry, G. E., Maloney, W., Arias, O. S., Fajnzylber, P., Mason, A. D., and Saavedra, J. (2007). Informality: Exit and Exclusion. The World Bank.

Ransom, M. R. and Sims, D. P. (2010). Estimating the Firm's Labor Supply Curve in a "New Monopsony" Framework: Schoolteachers in Missouri. Journal of Labor Economics, 28(2):331-355.

Scherer, C. (2015). Payroll tax reduction in Brazil: Effects on employment and wages. ISS Working Paper Series/General Series, 602(602):1-64.

Sokolova, A. and Sorensen, T. (2021). Monopsony in Labor Markets: A MetaAnalysis. ILR Review, 74(1):27-55.

Sokolova, A. and Sorensen, T. A. (2018). Monopsony in Labor Markets: A MetaAnalysis. IZA Discussion Papers 11966, Institute of Labor Economics (IZA).

Staiger, D. O., Spetz, J., and Phibbs, C. S. (2010). Is There Monopsony in the Labor Market? Evidence from a Natural Experiment. Journal of Labor Economics, 28(2):211-236.

Stock, J. and Yogo, M. (2002). Testing for weak instruments in linear iv regression. NBER Technical Working Papers 0284, National Bureau of Economic Research, Inc.

Tucker, L. (2017). Monopsony for Whom? Evidence from Brazilian Administrative Data. Job Market Paper.

Ulyssea, G. (2010). The formal-informal labor market segmentation hypothesis revisited. Brazilian Review of Econometrics, 30(2):311-334. 
Ulyssea, G. (2018). Firms, Informality, and Development: Theory and Evidence from Brazil. American Economic Review, 108(8):2015-2047.

Vick, B. (2017). Measuring links between labor monopsony and the gender pay gap in Brazil. IZA Journal of Migration and Development, 7(1):1-28.

Webber, D. A. (2015). Firm market power and the earnings distribution. Labour Economics, 35(C):123-134.

Werneck, R. L. F. (2013). Abertura, competitividade e desoneração fiscal. In Bacha, E. and Baumgarten, M., editors, O Futuro da Indústria no Brasil: desindustrilização em debate. Civilização Brasileira, Rio de Janeiro. 


\section{Appendix}

Table A.1: Summary statistics by population and sample

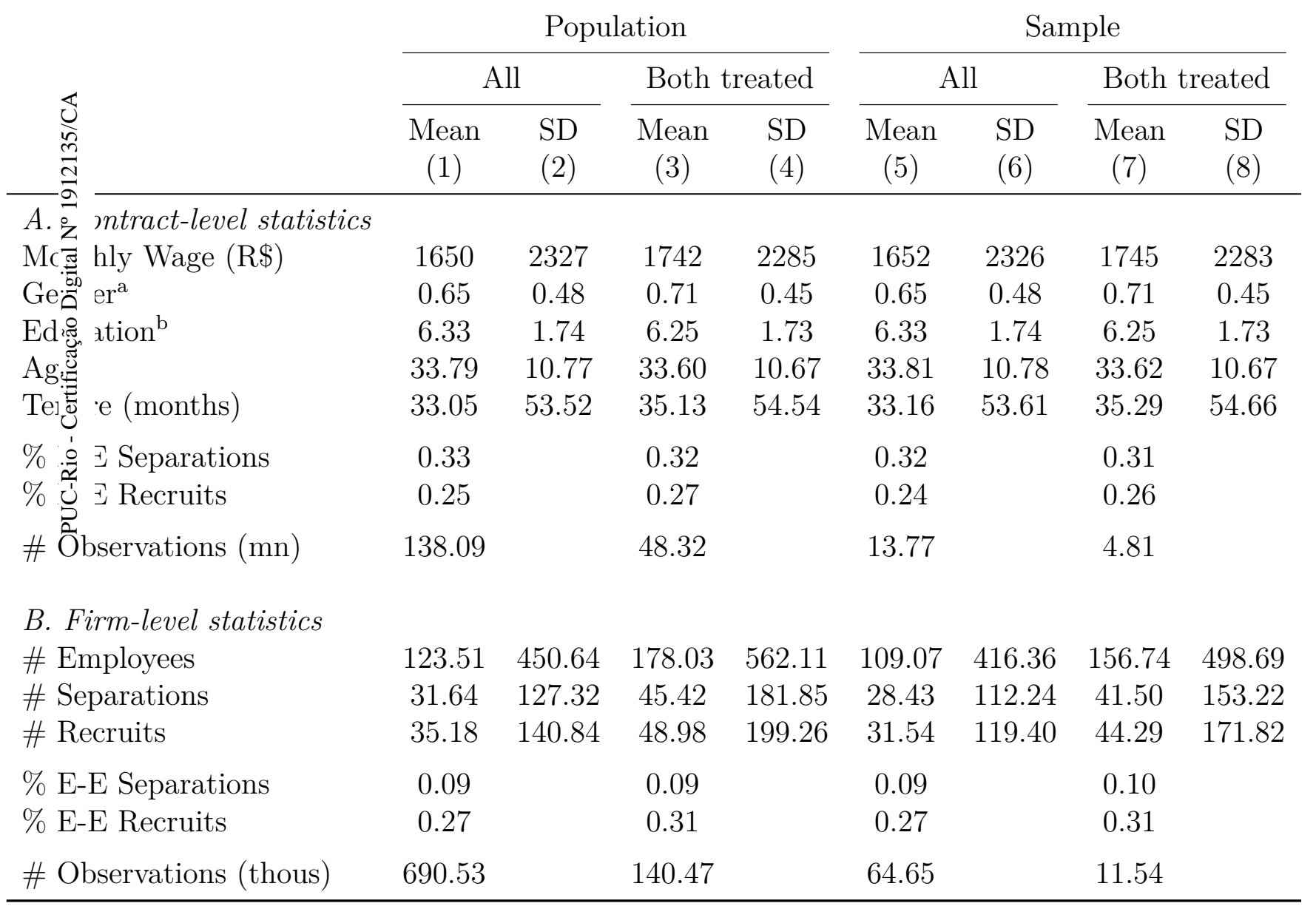

Notes: This table shows summary statistics on RAIS data for the period of 2012-2015, for both the full data sets and the samples used for the analyses of this paper. Panel (a) presents contract-level statistics, and an observation in this panel corresponds to a worker-firm-year. Panel (b) presents firm-level statistics created from the contract-level data. An observation in this panel corresponds to a firm-year.

${ }^{\text {a }}$ Takes a value of 1 if individual is male.

b Takes values from 1 to 11, corresponding to levels of education (for example, 1 indicates "illiterate", 6 indicates "high school incomplete" and 11 indicates "PhD"). 
Table A.2: Summary statistics for municipalities

\begin{tabular}{lccccc} 
& & & \multicolumn{3}{c}{ Percentiles } \\
\cline { 5 - 7 } & Mean & SD & $5^{\text {th }}$ & $50^{\text {th }}$ & $95^{\text {th }}$ \\
& $(1)$ & $(2)$ & $(3)$ & $(4)$ & $(5)$ \\
\hline A. Household-level statistics (\%) & & & & & \\
Urban area & 0.65 & 0.21 & 0.28 & 0.66 & 0.97 \\
Adequate housing & 0.31 & 0.26 & 0.00 & 0.25 & 0.77 \\
Electricity & 0.95 & 0.08 & 0.80 & 0.98 & 1.00 \\
Sewage service & 0.42 & 0.31 & 0.02 & 0.38 & 0.92 \\
Access to water & 0.68 & 0.20 & 0.30 & 0.71 & 0.94 \\
& & & & & \\
B. Individual-level statistics (\%) & & & & & \\
Both treated & 0.18 & 0.17 & 0.00 & 0.14 & 0.53 \\
Informal work & 0.11 & 0.04 & 0.06 & 0.11 & 0.17 \\
Bolsa Família benefit & 0.08 & 0.04 & 0.02 & 0.07 & 0.15 \\
Alphabetized & 0.84 & 0.09 & 0.67 & 0.87 & 0.95 \\
Mean per capita Wage (R $\$)$ & 565 & 266 & 243 & 536 & 1026 \\
\# Observations & 5565 & & & & \\
\hline
\end{tabular}

Notes: This table shows summary statistics corresponding to the 2010 Census data at the municipal level. Panel (a) reports statistics from the "Domicílio" data of the Census, while Panel (b) reports statistics on "Indivíduo" data. Aggregate measures at the municipal level were calculated using sample weights.

Figure A.1: Share treated by the payroll tax reform, by micro-region

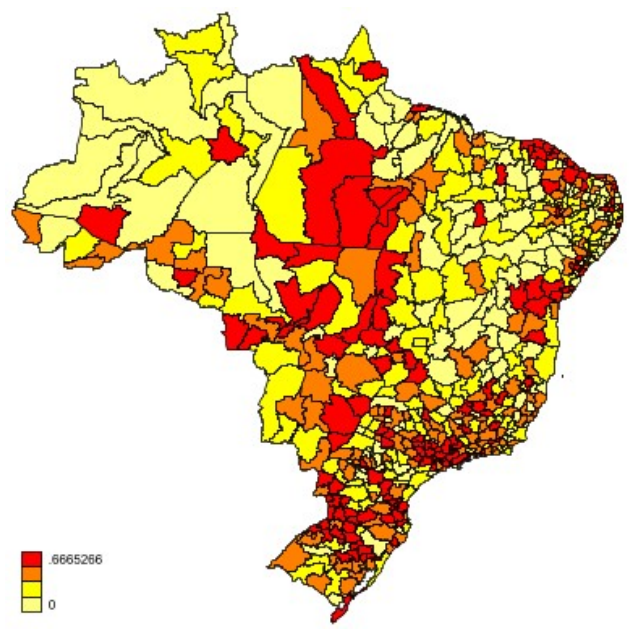

A. Contracts

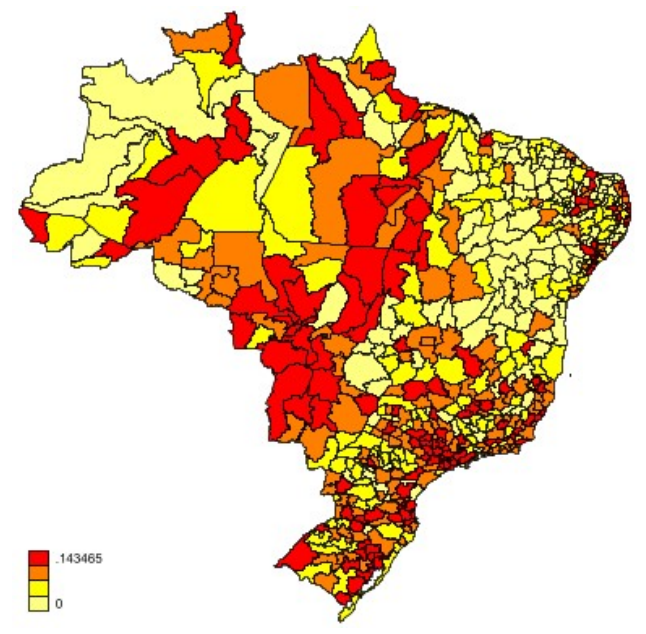

B. Firms

Notes: The figures show the share of observations in a given micro-region which are considered treated by the payroll tax reform, using both CNAE and NCM lists and the RAIS contract-level sample data from 2012 to 2015. An observation is a worker-firm-year in Panel (a), and a firm-year in Panel (b). 
Table A.3: Qualification level descriptions

Level The individual is able to...

$1 \quad$...apply general knowledge and concepts associated with simple tasks, that require basic skills and are executed under direct supervision.

$2 \quad$...apply general knowledge and basic technological concepts, skills with limited depth, to execute tasks and solve simple problems, under routine supervision, with limited autonomy and responsibility.

3 ...apply specialized technological concepts - including automation, robotizing, or other emerging technologies - and skills that allow for executing tasks and solving problems of intermediate complexity, under general supervision.

4 ...apply knowledge, concepts and technical procedures, management principals and skills that allow for solving specific issues and managing their activity. May supervise and evaluate routine activity of others.

$5 \quad$...apply broad general knowledge, specialized and theoretical, as well as skills that allow for conceiving creative solutions to specific problems, generally in an autonomous way. May assume supervision, development and review of third party performance responsibilities.

$6 \quad$...apply in-depth knowledge for a given area, with critical comprehension of theories and principles, as well as skills to solve complex and unpredictable problems. Manages activities, makes decisions with autonomy, and evaluates professional development of groups and individuals.

$7 \quad$...apply highly specialized knowledge, as well as skills for solving investigative and/or innovative problem. Manages under complex, unpredictable contexts that require strategic approaches. Makes decisions with autonomy, to improve strategic performance of teams.

8 ...apply cutting edge knowledge in a given area or at the intersection of multiple areas, as well as complex and highly specialized skills for investigative and innovative solutions. Autonomy in decision making and highly complex problem resolution, in unpredictable contexts.

Notes: The table presents descriptions of each level of qualification in the QBQ, which result from analyses of the complexity and/or depth of knowledge and skills, as well as autonomy and responsibility.

Source: Brazilian Ministry of Economy (2019). 
Table A.4: Summary statistics by QBQ skill level

\begin{tabular}{lccccc} 
& 1 & 2 & 3 & 4 & 5 \\
& $(1)$ & $(2)$ & $(3)$ & $(4)$ & $(5)$ \\
\hline Wage (R\$) & 856 & 1240 & 1740 & 2576 & 2685 \\
& $(518)$ & $(1108)$ & $(1649)$ & $(2527)$ & $(3018)$ \\
Gender $^{\mathrm{a}}$ & 0.65 & 0.65 & 0.69 & 0.64 & 0.63 \\
& $(0.48)$ & $(0.48)$ & $(0.46)$ & $(0.48)$ & $(0.48)$ \\
Education $^{\mathrm{b}}$ & 5.48 & 6.10 & 6.60 & 7.34 & 8.35 \\
& $(1.64)$ & $(1.62)$ & $(1.49)$ & $(1.23)$ & $(1.11)$ \\
Age & 33.63 & 33.17 & 33.97 & 34.65 & 32.21 \\
& $(11.56)$ & $(10.69)$ & $(10.52)$ & $(9.93)$ & $(8.51)$ \\
Tenure (months) & 20.44 & 28.79 & 40.22 & 50.74 & 37.88 \\
& $(35.14)$ & $(46.82)$ & $(60.19)$ & $(72.46)$ & $(52.21)$ \\
\% E-E Separations & 0.31 & 0.33 & 0.35 & 0.36 & 0.40 \\
\% E-E Recruits & 0.22 & 0.26 & 0.29 & 0.28 & 0.32 \\
\# Observations (mn) & 26.63 & 63.40 & 19.81 & 8.90 & 0.17 \\
\hline
\end{tabular}

Notes: This table shows summary statistics on RAIS contract-level data for the period of 2012-2015, and reports statistics for the first five levels of the QBQ. Standard deviations are reported in parentheses.

Table A.5: Robustness exercises for reduced CNAE sample Contract-level Firm-level

\begin{tabular}{|c|c|c|c|c|c|c|}
\hline & & \\
\hline & (1) & $(2)$ & $(3)$ & $(4)$ & $(5)$ & $(6)$ \\
\hline E-E Separation $\varepsilon_{s w}^{e}$ & 0.14 & 1.43 & 1.45 & 0.40 & 0.33 & 0.58 \\
\hline E-N Separation $\varepsilon_{s w}^{u}$ & 0.45 & 1.42 & 1.41 & 0.15 & 0.32 & 0.30 \\
\hline E-E Recruitment $\varepsilon_{\theta_{R}}$ & 0.56 & 0.57 & 0.64 & 0.86 & 0.68 & 0.72 \\
\hline$\%$ E-E Separations & 0.33 & 0.33 & 0.33 & 0.34 & 0.34 & 0.34 \\
\hline$\%$ E-E Recruits & 0.25 & 0.25 & 0.25 & 0.25 & 0.25 & 0.25 \\
\hline Labor supply $\varepsilon_{N w}$ & $\begin{array}{l}-1.09 \\
(0.39)\end{array}$ & $\begin{array}{l}-3.91 \\
(1.15)\end{array}$ & $\begin{array}{l}-4.00 \\
(1.13)\end{array}$ & $\begin{array}{l}-1.64 \\
(0.07)\end{array}$ & $\begin{array}{l}-1.46 \\
(0.10)\end{array}$ & $\begin{array}{l}-1.92 \\
(0.11)\end{array}$ \\
\hline $\begin{array}{l}\text { Year + Region FE } \\
\text { Controls }\end{array}$ & & Yes & $\begin{array}{l}\text { Yes } \\
\text { Yes }\end{array}$ & & Yes & $\begin{array}{l}\text { Yes } \\
\text { Yes }\end{array}$ \\
\hline Observations (mn/thous) & & & & & & \\
\hline E-E Separation & 6.80 & 6.80 & 6.80 & 399.99 & 394.17 & 394.17 \\
\hline E-N Separation & 7.53 & 7.53 & 7.53 & 400.04 & 394.21 & 394.21 \\
\hline E-E Recruitment & 2.48 & 2.48 & 2.48 & 391.12 & 385.45 & 385.45 \\
\hline
\end{tabular}

Notes: All columns use only sectors included in the payroll tax reform through the CNAE list in the IV treatment variable, and exclude sectors from the sample which were treated through the NCM list. Standard errors are reported in parenthesis and are clustered at the firm level. 
Figure A.2: Share of households in urban areas, by micro-region

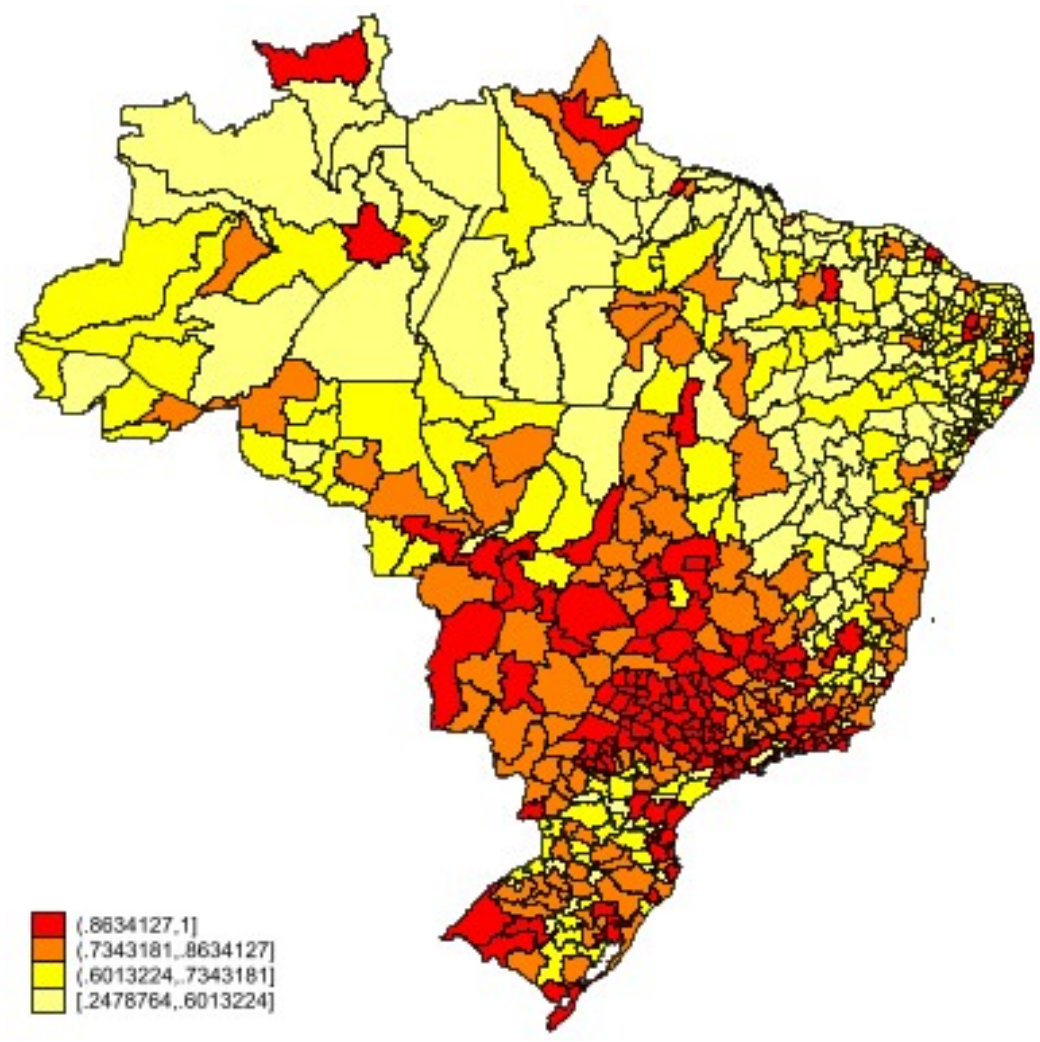

Notes: The figure shows the share of households in a given micro-region which report being located in an urban area, calculated using household-level data from the 2010 Brazilian Census. 
Figure A.3: Share of workers in the informal sector, by micro-region

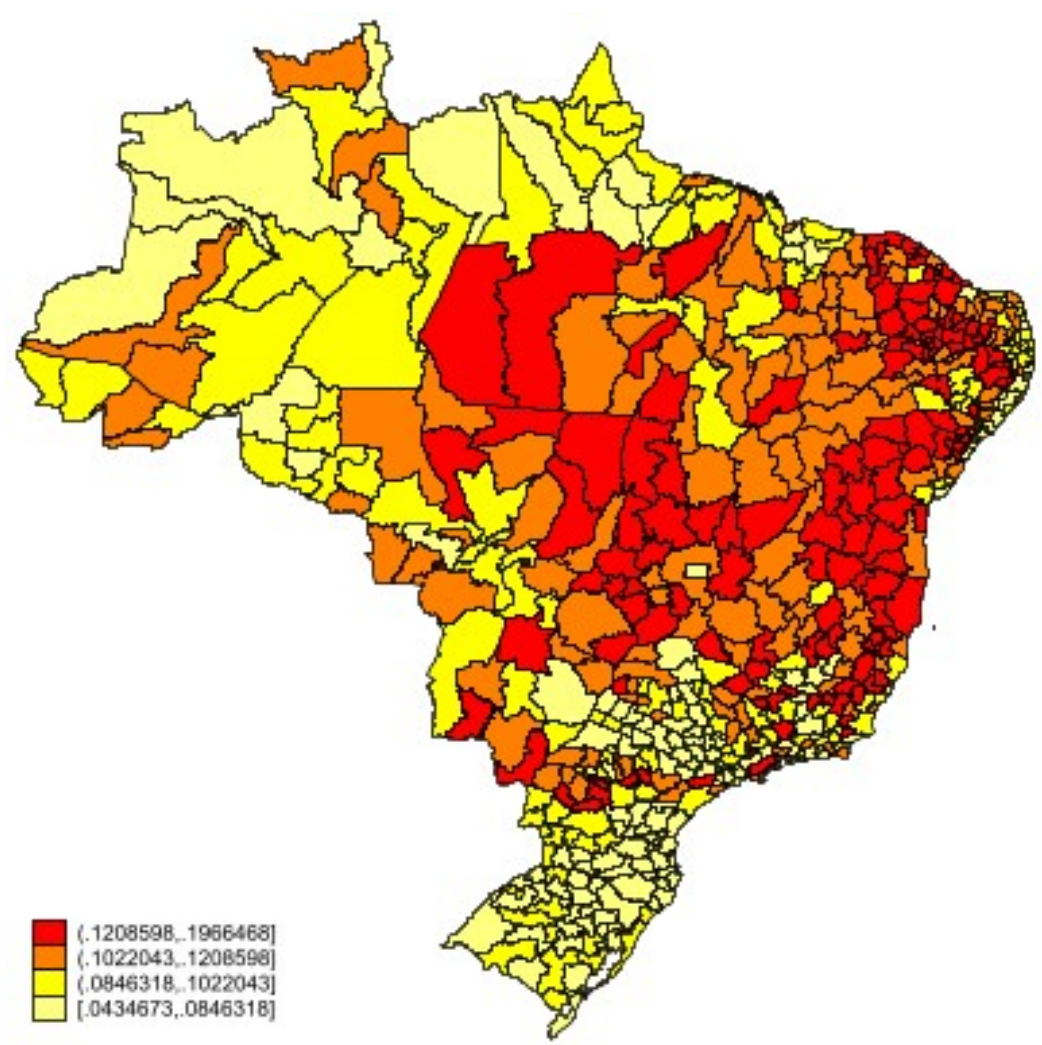

Notes: The figure shows the share of individuals in a given micro-region who report working in the informal sector, calculated using individual-level data from the 2010 Brazilian Census. 